\title{
Freshwater actinopterygians of the Los Rastros Formation (Triassic), Bermejo Basin, Argentina
}

\author{
Adriana López-Arbarello*, ${ }^{*}$ Raymond Rogers ${ }^{2}$, \& Pablo Puerta ${ }^{3}$ \\ ${ }^{1}$ Bayerische Staatssammlung für Paläontologie und Geologie, Richard-Wagner-Str. 10, D-80333 München, Germany \\ 2 Geology Department, Macalester College, 1600 Grand Avenue, Saint Paul MN 55105, U.S.A. \\ ${ }^{3}$ Museo Paleontológico Egidio Feruglio, Fontana 140, 9100 Trelew, Argentina
}

Received 5 February 2006, accepted 12 March 2006

Published online 17 July 2006

With 12 figures

Key words: Actinopterygii, Acrolepidae, Triassic, South America, Argentina.

\begin{abstract}
The present paper includes detailed descriptions of all fossil fishes known from the Los Rastros Formation (Ladinian; Bermejo Basin, Argentina). Four taxa are identified: Gualolepis carinaesquamosa n. gen.n. sp., Rastrolepis n. gen. with two species $R$. riojaensis $\mathrm{n}$. sp. and R. latipinnata $\mathrm{n}$. sp., and Challaia elongata $\mathrm{n}$. comb. Gualolepis $\mathrm{n}$. gen. and Rastrolepis $\mathrm{n}$. gen. are incertae sedis actinopterygians. The opercular bones of Gualolepis resemble those in peipiaosteid acipenseriforms and the fish might be related with the Chondrostei. The most distinctive features of Rastrolepis are the narrow opercular region and the presence of a very large plate-like branchiostegal bone resembling the condition in the Redfieldiiformes. Challaia elongata, originally described in the Australian genus Myriolepis, is here refered to the genus Challaia, previously known from the nearby Cuyo Basin and representing the first fish taxon common to both continental sequences. Furthermore, Challaia is shown to be a member of the Acrolepidae and represents the youngest record of the family in Gondwana.
\end{abstract}

Schlüsselwörter: Actinopterygii, Acrolepidae, Trias, Südamerika, Argentinien.

\section{Zusammenfassung}

Alle fossilen Fische, die bisher von der Los Rastros Formation (Ladin; Bermejo-Becken, Argentinien) bekannt sind, werden im Detail beschrieben. Vier Taxa können identifiziert werden: Gualolepis carinaesquamosa n. gen. n. sp., Rastrolepis n. gen., mit zwei Arten, R. riojaensis n. sp. und R. latipinnata n. sp., und Challaia elongata comb. nov. Gualolepis n. gen. und Rastrolepis n. gen. Actynopterygier unsicherer systematischer Stellung. Die Operkular-Knochen von Gualolepis ähneln jenen der peipiaosteiden Acipenseriformen und das Taxon mag mit den Chondrostei verwandt sein. Die auffälligsten Merkmale von Rastrolepis sind die sehr schmale Operkularregion und das Vorhandensein eines sehr großen, plattigen Branchiostegale, das dem Zustand in Redfieldiiformen ähnelt. Challaia elongata, ursprünglich zu der australischen Gattung Myriolepis gestellt, wird hier der Gattung Challaia zugeordnet, die bisher nur aus dem nahegelegenen Cuyo-Becken bekannt war und repräsentiert somit das erste Fisch-Taxon, das in beiden Sequenzen vorkommt. Zudem kann gezeigt werden, dass Challaia zu den Acrolepidae gehört und somit den jüngsten Nachweis dieser Gruppe in Gondwana darstellt.

\section{Introduction}

The Triassic saw important changes in the composition of fish faunas, with the radiation and ex- tinction of several groups of basal actinopterygians and the appearance of the first teleosts. Although the Triassic is thus an important stage in fish evolution, in comparison with younger

\footnotetext{
* Corresponding author: e-mail: a.lopez-arbarello@Irz.uni-muenchen.de
} 
Mesozoic ichthyofaunas, the Triassic fish faunas are still relatively poorly known. This is especially true for the Southern Hemisphere.

From South America, continental Triassic fishes are known only from three different geological units: the Santa María Formation of southern Brazil and units in the Cuyo and Bermejo (= Ischigualasto-Villa Unión, see Stipanicic 1983, 2002; Stipanicic \& Bonaparte 1979) basins of northwestern Argentina. Whereas the Santa María Formation has only yielded some fragmentary and as yet undescribed remains, a rich fish fauna was described from the Cuyo Basin
(López-Arbarello 2004). Unfortunately, most of these fishes were only very poorly described in journals with very low circulation outside of Argentina and thus, to this day they remain largely unknown. Although the described material is often poorly preserved, a diversity of fishes is evidently present in several formations within the Cuyo Basin and a detailed taxonomic revision of these faunas is currently being undertaken by the senior author.

The Bermejo Basin is famous for its diverse and important tetrapod fauna (e.g., Bonaparte 1997), but fossil fishes are very rare in the Trias-
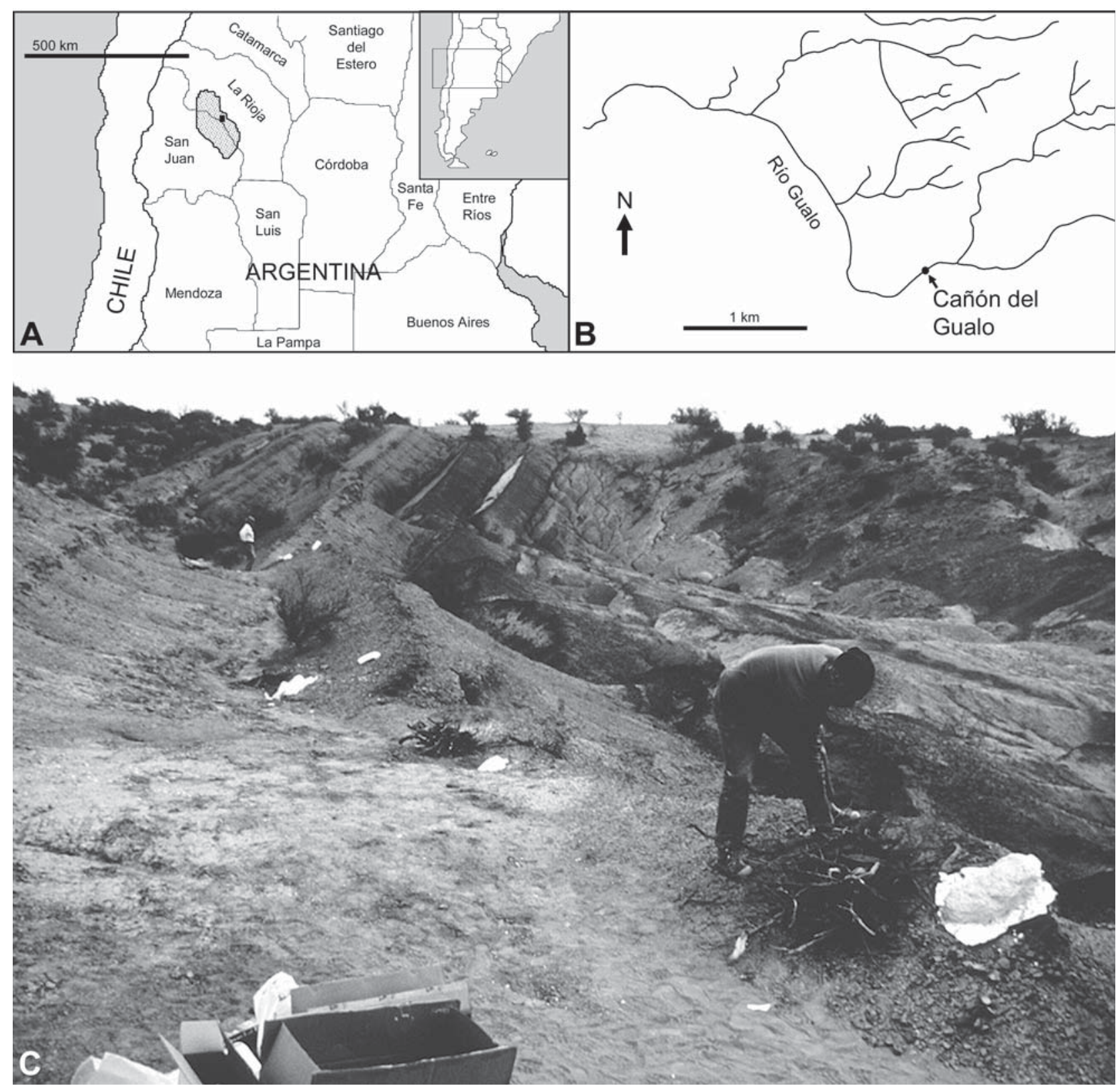

Fig. 1. Geographic location of the fish locality: $\mathbf{A}$ - Simplified map of southern South America (upper right corner) and central Argentina, indicating the location of the Bermejo Basin (dotted area) and the fish locality (black square); $\mathbf{B}-$ map of the Gualo river system indicating the location of the fish locality at Cañón del Gualo (modified from Rogers et al. 2001); C photograph of the fish locality showing the $5^{\text {th }}$ lacustrine hemicycle of the Los Rastros Formation and the fish bearing horizon, with the fishes in plaster jackets (photo courtesy C. May). 
sic sediments of this basin. Apart from isolated scales, articulated fish remains have so far only been reported from the Los Rastros Formation. Prior to our work, only one fish taxon had been described from this formation, Myriolepis elongata Cabrera, 1944, based on the remains of a large basal actinopterygian found in the exposures of Agua de La Peña Creek, San Juan Province, Argentina. In 1995, a joint American/Argentinean expedition recovered more fishes from sandstone concretions within the Los Rastros Formation, though from a different locality than the holotype specimen of M. elongata. Among the fishes collected from this new locality (herein referred to as the Cañón del Gualo locality), we found high diversity including four different species of basal actinopterygian fishes represented in only five concretions.

\section{Geological and paleontological settings}

The continental Bermejo Basin is one of several extensional basins that formed along the western margin of South America during the initial stages of the breakup of Pangea (Uliana \& Biddle 1988; Ramos \& Kay 1991; Stipanicic 2002). The basin is subdivided into two groups separated by a regional unconformity (Fig. 1). The Scythian to Anisian Paganzo III Group consists of the alluvial deposits of the Talampaya and Tarjados formations. The overlying Ladinian to Norian Agua de la Peña Group includes five formations that represent various terrestrial paleoenvironments, which in ascending order include: Chañares, Ischichuca, Los Rastros, Ischigualasto and Los Colorados formations (de la Mota 1946; Bossi 1971; Stipanicic 1983, 2002; Milana \& Alcober 1994; Rogers et al.
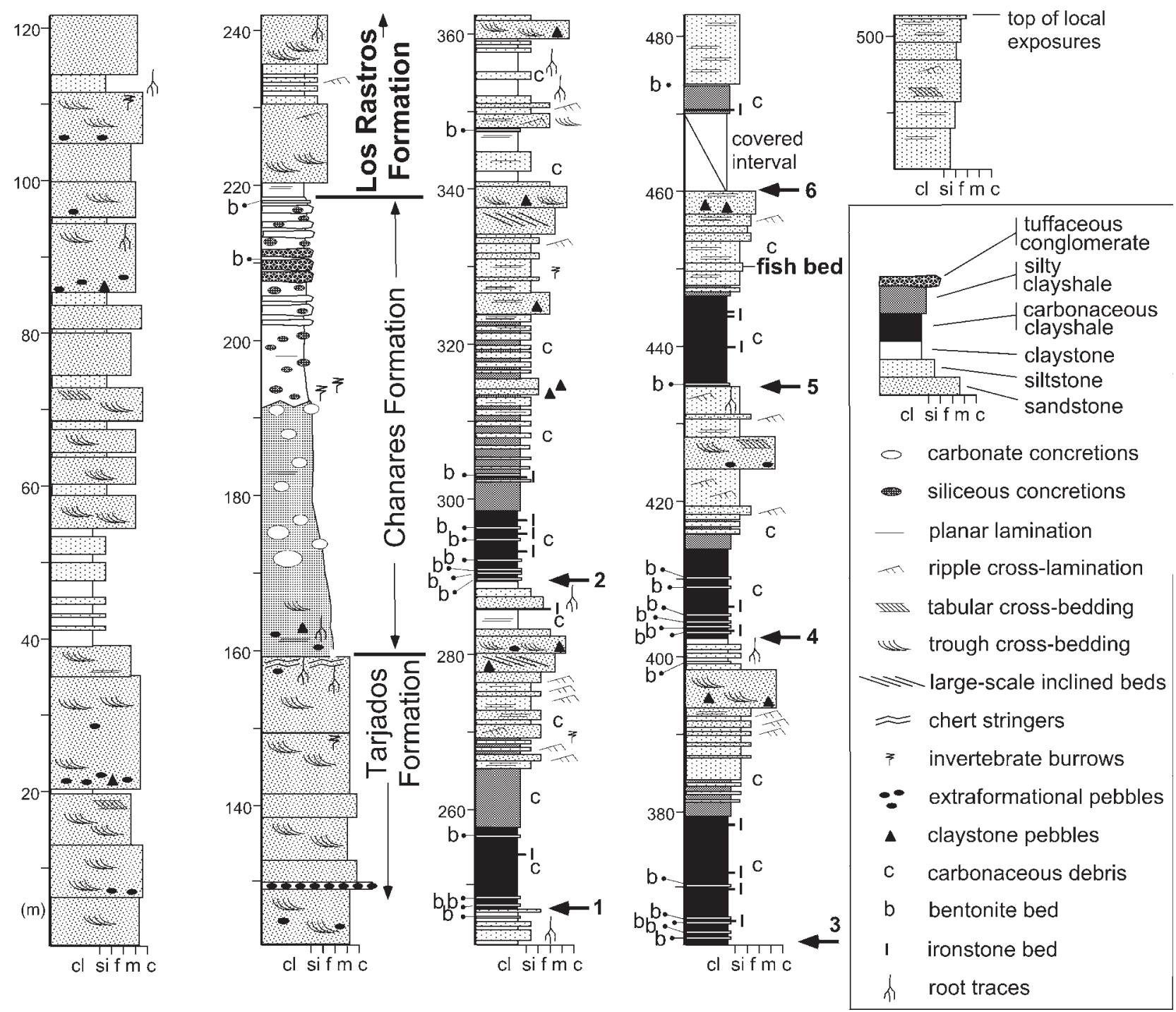

Fig. 2. Graphic stratigraphic logs of the Tarjados, Chañares, and Los Rastros formations: Composite section measured in the vicinity of Cañón del Gualo indicating the stratigraphic position of the fish bed. Horizontal arrows indicate the bases of the six lacustrine hemicycles in the Los Rastros Formation (modified from Rogers et al. 2001). 
2001). Among the units of the Agua de la Peña Group, only the Los Rastros Formation is known to preserve fossil fishes.

Although isolated fish remains (scales, bone fragments, fin rays, etc.) are common throughout the stacked lacustrine cycles that comprise the Los Rastros Formation (Fig. 2), articulated fish remains are only known from a layer of concretions in the upper part of the formation (Rogers et al. 2001, Mancuso 2003). A radiometric age of 228 m.y. $\left({ }^{40} \mathrm{Ar} /{ }^{39} \mathrm{Ar}\right.$; Rogers et al. 1993) from the lower part of the overlying Ischigualasto Formation suggests a Ladinian age for the Los Rastros Formation (Rogers et al. 2001). Biostratigraphic correlations are suggestive of a slightly younger, Carnian age for this formation (Stipanicic \& Bossi 2002). Apart from archosaur tracks identified as Rigalites ischigualastianus Huene, 1931, and remains of an undescribed temnospondyl (Contreras et al. 1997), fishes are the only vertebrate remains known from the Los Rastros Formation. Other fossils known from this formation include a rich palyno and megaflora, conchostracans, and insects (Gallego 1997; Stipanicic \& Bossi 2002, Mancuso 2003).

\section{Material and Methods}

The studied material belongs to the following institutions: MCNAM, Museo de Ciencias Naturales y Antropológicas "Juan Cornelio Moyano" Mendoza, Argentina; MLP, Museo de La Plata, La Plata, Argentina; PULR, Paleontological collection of the Universidad Nacional de La Rioja, La Rioja, Argentina.

Except for the holotype of Challaia elongata, all the other fishes described here from the Los Rastros Formation were preserved in well-indurated sandstone concretions. At the time of collection, the fishes were partially exposed due to weathering. After collection, the specimens were stored in plaster jackets for approximately five years. Minor disarticulation of poorly preserved scales occurred during storage. Once the jackets were opened, the fishes were mechanically prepared.

The holotype of Challaia elongata is preserved in a dark gray siltstone. For exhibition purposes the fossil had been painted with a thick lacquer, which was chemically removed to allow its study. Afterwards, further details of the fish were exposed by mechanical preparation.

According to the current use in Phylogenetic Systematics, we follow an unranked systematic hierarchy. Skull bones are named according to Jollie (1962), Schultze \& Arsenault (1985), Schultze (1993), and Arratia \& Cloutier (1996). The nomenclature used for the caudal skeleton is according to Hilton (2004). The relative position of the fins and the scale counts is expressed in a pterygial formula where D, P, A, and $\mathrm{C}$ indicate the number of scale rows between the first complete row behind the pectoral girdle and the insertion of the dorsal, pelvic, anal, and caudal fins respectively, and $\mathrm{T}$ is the total number of scale rows between the pectoral girdle and the caudal inversion (Westoll 1944).

\section{Systematic Paleontology}

Osteichthyes Huxley, 1880

Actinopterygii Cope, 1887

Actinopterygii incertae sedis

\section{Gualolepis n. gen.}

Derivation of name. After the type locality "Cañón del Gualo", and "lepis" (Greek), a scale.

Type species. Gualolepis carinaesquamosa $\mathrm{n}$. sp.

Diagnosis. As for the type and only known species.

\section{Gualolepis carinaesquamosa n. sp.}

Figs $3 \mathrm{~A}-\mathrm{C}$

Derivation of name. For "carina" (Latin), a keel, and "squama" (Latin), a scale, in reference to the peculiar ornamentation of the scales.

Syntypes. PULR 106 and 107. Only specimens.

Type locality. Vicinity of Cañón del Gualo (S: $29^{\circ} 53^{\prime} 38.3^{\prime \prime}$, W: $67^{\circ} 46^{\prime} 21.2^{\prime \prime}$ ), La Rioja province, Argentina (Fig. 1).

Formation and age. Los Rastros Formation (Ladinian), Bermejo Basin, fifth lacustrine hemicycle (see Rogers et al. 2001) (Fig. 2).

Diagnosis. The following diagnosis is based on a unique combination of characters. Operclulum as deep as wide and reduced, less than half the size of suboperculum; suboperculum 1.15 times wider than deep, narrowing slightly dorsally; large supracleithrum, about 5 times deeper than wide, about 1.15 times deeper than suboperculum; flank scales ornamented with vertical median ridges, which are aligned along transverse row of scales.

Description. PULR 106 includes the anterior portion of the body without fins, with some skull bones and partially preserved elements of the pectoral girdle. PULR 107 includes imprints of the skull and anterior portion of the trunk. Scale features are somewhat better preserved in this specimen.

The lower jaw seems to have been very shallow, tapers anteriorly and is shorter than the upper jaw. PULR 106 preserves the operculum, suboperculum, some branchiostegal elements, supracleithrum and part of the cleithrum in mesial view (Fig. 3A, B). The operculum is very reduced and somewhat rounded. It is as wide as deep, les than half the depth and about half the width of the suboperculum. The suboperculum is 1.15 times wider than deep, narrowing slightly dorsally and with gently rounded borders. Only a few branchiostegals are preserved, but they seem to have been numerous. The supracleithrum is large, about 5 times deeper than wide, and deeper than the suboperculum. Its outline is 

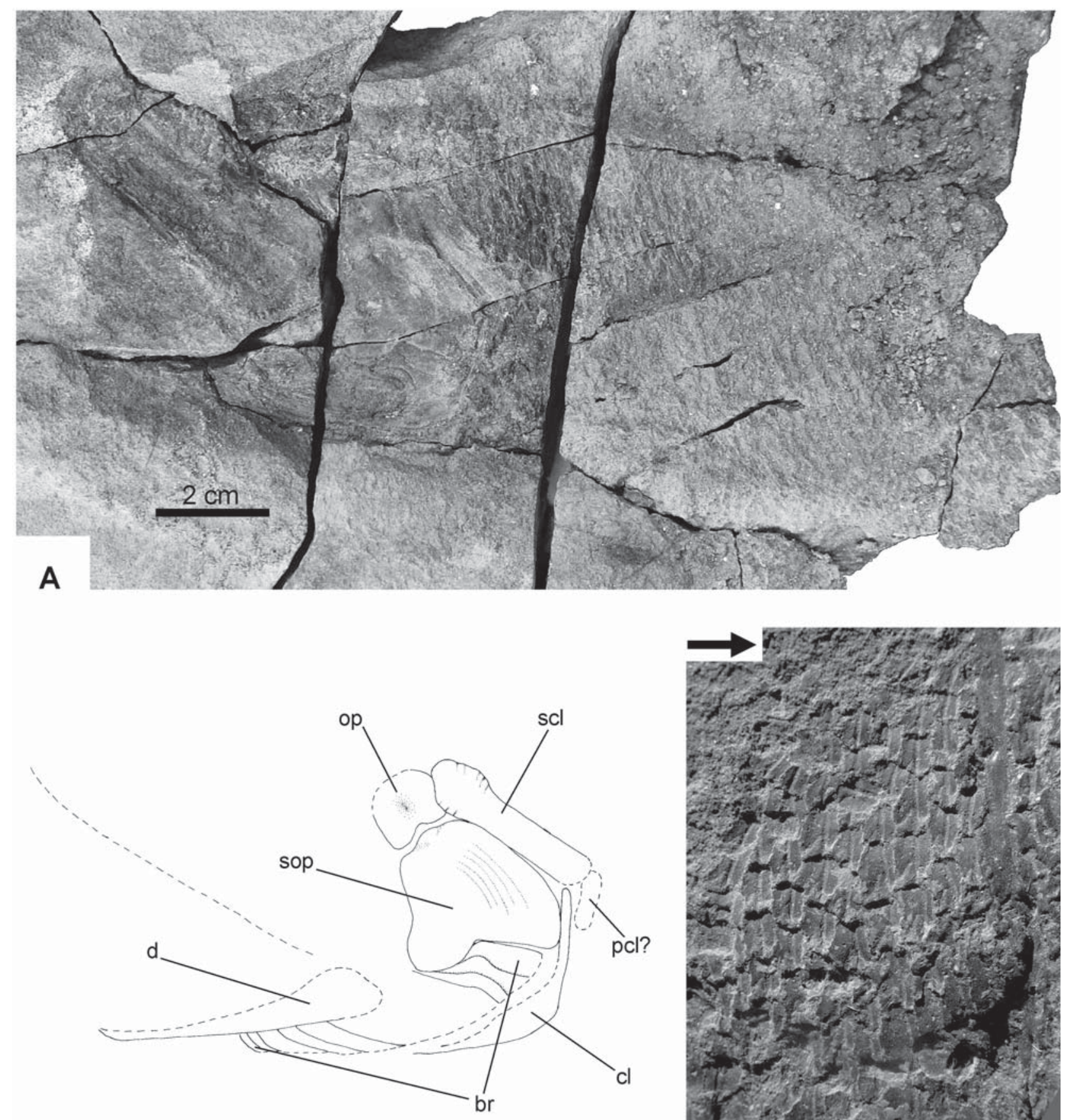

$2 \mathrm{~cm}$

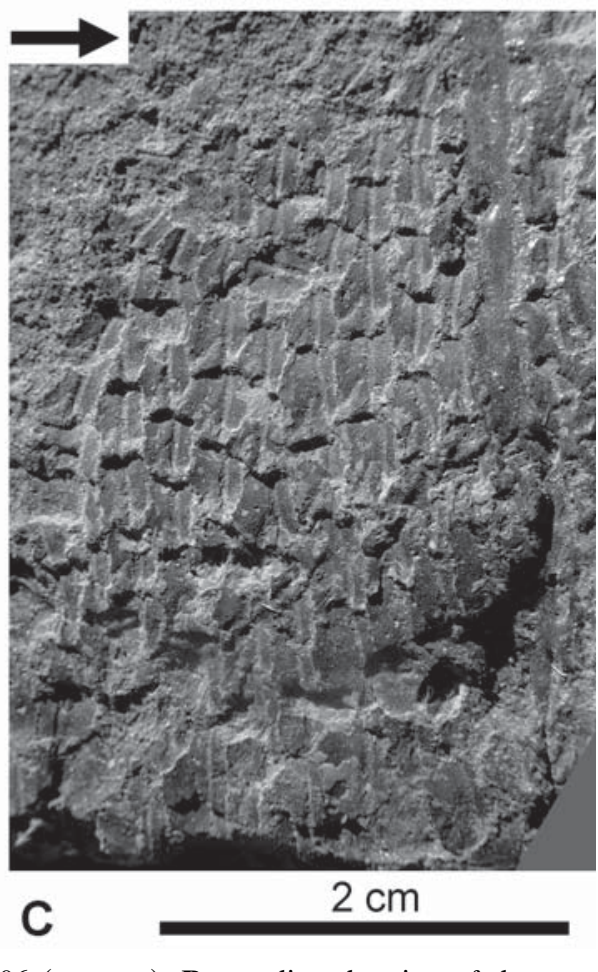

B

Fig. 3. Gualolepis carinaesquamosa n. gen. n. sp. A - left lateral view of PULR 106 (syntype); $\mathbf{B}$ - outline drawing of the preserved elements in the skull of PULR 106 (syntype); C-detail of the external mould of the anterior flank scales in PULR 107 showing the peculiar ornamentation with a median vertical ridge; arrow points anteriad. Abbreviations: br - branchiostegal bones; cl - cleithrum; d - dentalosplenial; op - operculum; pcl? - postcleithrum?; scl - supracleithrum; sop - suboperculum.

approximately rectangular with a slightly expanded dorsal portion. Very little of the cleithrum is preserved. It apparently reached the lower jaw anteriorly and is relatively slender.

The internal view of the anteriormost flank scales is poorly preserved in PULR 106 . They are about 2.5 times deeper than long. They pre- sent peg and socket articulations, with a narrowly based, conical and shallow peg. PULR 107 preserves the external mold of the scales showing that they turned quadrangular posteriorly and that they were ornamented. The ornamentation consists of an approximately median ridge parallel to the posterior border of the scale 
(Fig. 3C). The ridges of individual scales seem to have been aligned in a continuous line following each transverse row of scales. The preservation is not good enough to decide about the presence of gaonine on the scales or the skull bones.

Discussion. Gualolepis carinaesquamosa closely resembles peipiaosteid acipenseriforms (e.g. Stichopterus and Peipiaosteus; Grande \& Bemis 1996) in the characteristics of the opercular bones, with rounded elements and very reduced operculum. In most basal actinopterygians the operculum is larger than the suboperculum and this is considered the primitive condition in the group (Lund et al. 1995; Lund 2000; Cloutier \& Arratia 2004). The suboperculum is slightly larger than the operculum in perleidiforms (Gardiner \& Schaeffer 1989; Tintori \& Sassi 1992), but an operculum considerably smaller than the suboperculum is considered a synapomorphy of Chondrostei (Bemis et al. 1997). Consequently, G. carinaesquamosa probably represents a primitive Chondrostei (sensu Patterson 1982), but so little is known about this fish that its referral to any major group of actinopterygians cannot be confidently established and thus, it should be kept as Actinopterygii incertae sedis.

\section{Rastrolepis n. gen.}

Derivation of $n$ ame. For the Los Rastros Formation, the geological unit from which this fish was recovered, and the Greek "lepis", a scale.

Type species. Rastrolepis riojaensis $\mathrm{n}$. $\mathrm{sp}$.

Other species. R. latipinnata $\mathrm{n}$. sp.

Diagnosis. The following diagnosis is based on a unique combination of characters. Large actinopterygians with fusiform bodies; narrow opercular series; large branchiostegal plate, of about the same size of suboperculum and as deep as the lower jaw; large supracleithrum; pectoral fin insertion very low; dorsal fin opposite to anal fin; both dorsal and anal fin-rays evenly segmented starting at their bases, bifurcated distally, and ornamented with a median ridge parallel to the axis of the ray; caudal fin hemiheterocercal; rounded distal end of scaly lobe; very small basal fulcra preceding dorsal and anal fins; small and numerous fringing fulcra on all fins.

Discussion. A very peculiar condition in Rastrolepis is the presence of a very large branchiostegal plate. The first branchiostegal ray is always the largest in basal actinopterygians, but it is notably smaller than the suboperculum in most cases. Enlarged branchiostegal elements reduced to one or two platelike bones are considered to be a synapomorphy of the Redfieldiiformes by Schaeffer (1984). The first or single branchiostegal plate in redfieldiiforms, although usually notably smaller than the suboperculum, approxi- mately equals the depth of the lower jaw in some genera (Dictyopyge, Molybdichthys, Schizurichthys; Hutchinson 1973, Schaeffer \& Mc Donald 1978, Schaeffer 1984). The reduction in the number of branchiostegal rays also occurred in haplolepids, aeduellids, and polyodontids (except Protopsephurus). However, the very specialized haplolepids clearly differ from Rastrolepis in many features such as the small number of scale rows, the rather vertical suspensorium, the structure of the fins in which the rays are few, stout and not bifurcated (Westoll 1944; Poplin 1997). Similarly, aeduellids differ from Rastrolepis in features such as the vertical suspensorium and the strongly heterocercal tail (Heyler 1969; Poplin 2001). Polyodontids are very specialized fishes within a very primitive lineage, the Chondrostei (sensu Patterson 1982), with heterocercal tails and very reduced squamation among many distinctive features. Furthermore, although the branchiostegal rays are reduced in these three groups, the condition displayed by them (for more details see Westoll 1944; Heyler 1969; Grande \& Bemis 1996) is clearly different from that in Rastrolepis and most redfieldiiforms in which the first or single branchiostegal element is represented by a comparatively very large platelike bone, frequently as deep as the lower jaw. The total number of branchiostegal rays is unknown in Rastrolepis and most redfieldiiform synapomorphies are in the snout region, which is not preserved in any of the specimens of the new genus. No other feature in Rastrolepis allows any hypothesis of relationships among basal actinopterygians. Therefore, due to incomplete preservation, Rastrolepis cannot be referred to Redfieldiiformes or any other actinopterygian group.

Two species are recognized in Rastrolepis. The skull is incompletely known in both species. However, R. riojaensis and R. latipinnata clearly differ in the shape and proportions of the supracleithrum, the number of basal fulcra preceding the dorsal fin ( 5 vs. 1$)$, and the number of finrays in the anal (26 vs. 41 ) and caudal (40 vs. 60 ) fins (see below).

\section{Rastrolepis riojaensis n. sp.}

Figs 4-6

Derivation of name. For the province of La Rioja, where this fish was found.

Holotype. PULR 103A and 103B. Only specimen.

Type locality. Vicinity of Cañón del Gualo (S: $29^{\circ} 53^{\prime} 38.3^{\prime \prime}$, W: $\left.67^{\circ} 46^{\prime} 21.2^{\prime \prime}\right)$, La Rioja province, Argentina (Fig. 1). 


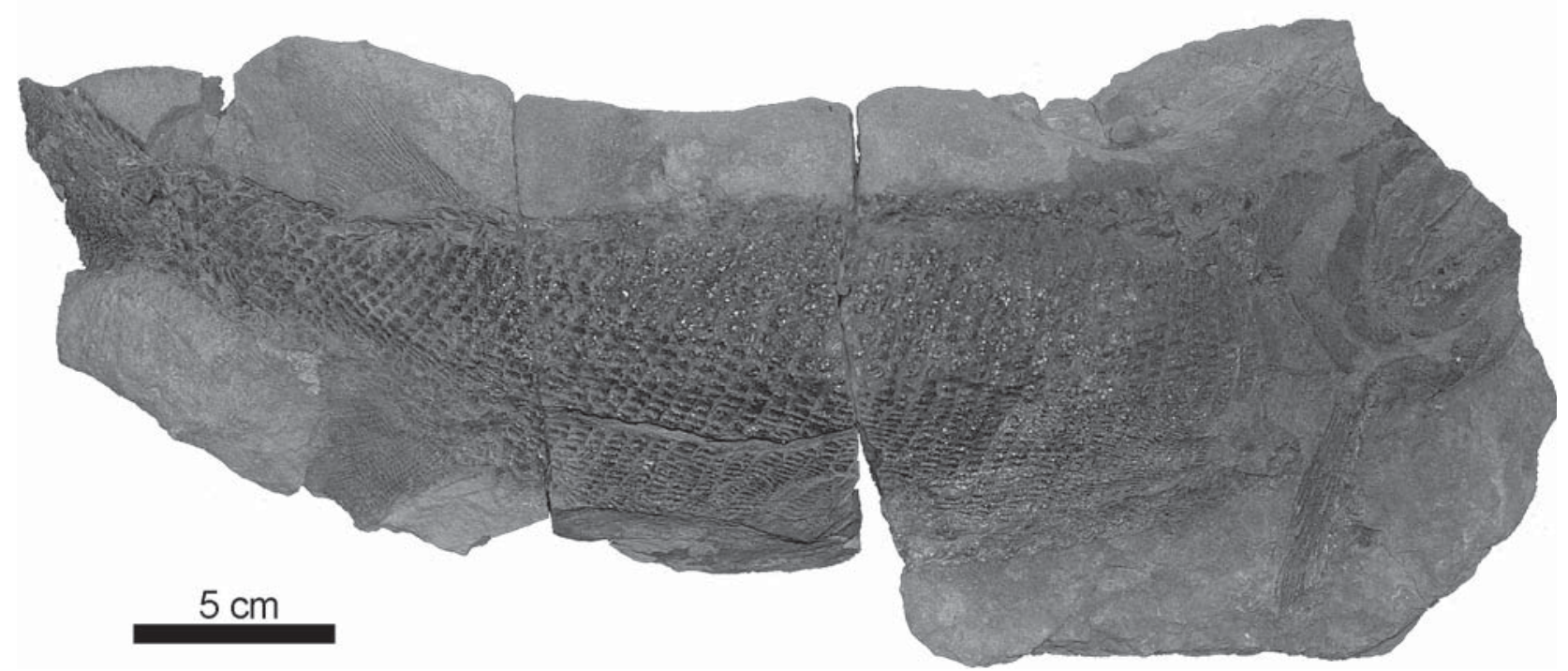

Fig. 4. Rastrolepis riojaensis n. gen. n. sp. Right lateral view of PULR 103A (holotype).

Formation and age. Los Rastros Formation (Ladinian), Bermejo Basin, fifth lacustrine hemicycle (see Rogers et al. 2001) (Fig. 2).

Diagnosis. The following diagnosis is based on a unique combination of characters. Preoperculum narrow, with no distinct anterior and ventral arms; postorbital plate of the maxilla large, high, and elongated; branchiostegal plate about 0.8 times the depth and width of suboperculum; approximately triangular supracleithrum about 2.8 times deeper than wide, approximately as wide as, but 1.3 times deeper than suboperculum; pectoral fin with 13 distally segmented and bifurcated rays; dorsal fin opposite to anal fin; dorsal and anal fins of comparable size, the length of their bases being $13 \%$ of the distance between cleithrum and end of scaly lobe; dorsal with 20 rays, anal with about 26 rays; dorsal fin preceded by 5 slender basal fulcra; caudal fin hemiheterocercal with about 40 rays; small dorsal and ventral scutes preceding caudal fin; ventral flank scales very shallow; pterygial formula:

$$
\frac{\mathrm{D} 41}{\mathrm{P} 17 \text { A34 C57 }} \text { T60 }
$$

Description. The holotype and only specimen is a fusiform elongated fish more than $390 \mathrm{~mm}$ in length (total length of the fossil; Fig. 3). The real proportions of the head and tail are unknown, but the total length of the fish might have been around $450 \mathrm{~mm}$ or more. The length from the posterior border of the cleithrum to the end of the scaly lobe of the tail (CT length) is $290 \mathrm{~mm}$. The maximum height of the body, about the level of the pelvic fin origin, is $88 \mathrm{~mm}$, which is about $20 \%$ of the estimated total length. The height of the body at the origins of the dorsal and anal fins is $62 \mathrm{~mm}$. The bones of the dermal-skull and pectoral girdle are ornamented (see below). There is no sign of a lateral line. The body is covered with ganoid scales, which vary in size and shape in different parts of the body. Small and numerous fringing fulcra are clearly preserved in all fins with the exception of the dorsal edge of the caudal fin, in which it is not possible to establish whether they were present or not. Due to the imperfect preservation, the presence of ganoine cannot be established.

Skull - Only the left and right external molds of the posterior part of the skull are preserved (Fig. 4). The sensory canals, except for the preopercular canal, cannot be distinguished, the outline of various bones is not complete, and most elements are somewhat displaced. Therefore, a complete reconstruction of the skull was not possible and the present interpretation of the skull might be modified when more material becomes available.

The preoperculum is very inclined. It has no clearly distinct anterior and ventral arms, its ventral portion is very narrow and it expands gradually anterodorsally. Only the large postorbital plate of the maxilla is preserved, which is high and elongated (Fig. 5A, B). In PULR 103B, there are two bony elements anterodorsal to the maxilla and anterior to the preoperculum (Fig. 5C, D). The posterior element, which is partially overlapped by the displaced preoperculum, might represent a suborbital. The anterior element is fragmented and might represent the posterior portion of the last infraorbital bone. Dorsal to these elements, a partially preserved bone might represent a relatively large dermosphenotic. In PULR $103 \mathrm{~A}$, a quadratojugal is apparently present at the base of the preoperculum (Fig. 5A, B). The angular is elongated and narrow, forming the whole posteroventral angle of the lower jaw. The dentalosplenial is large and deep; its posterior portion being as deep as the posterior portion of the max- 

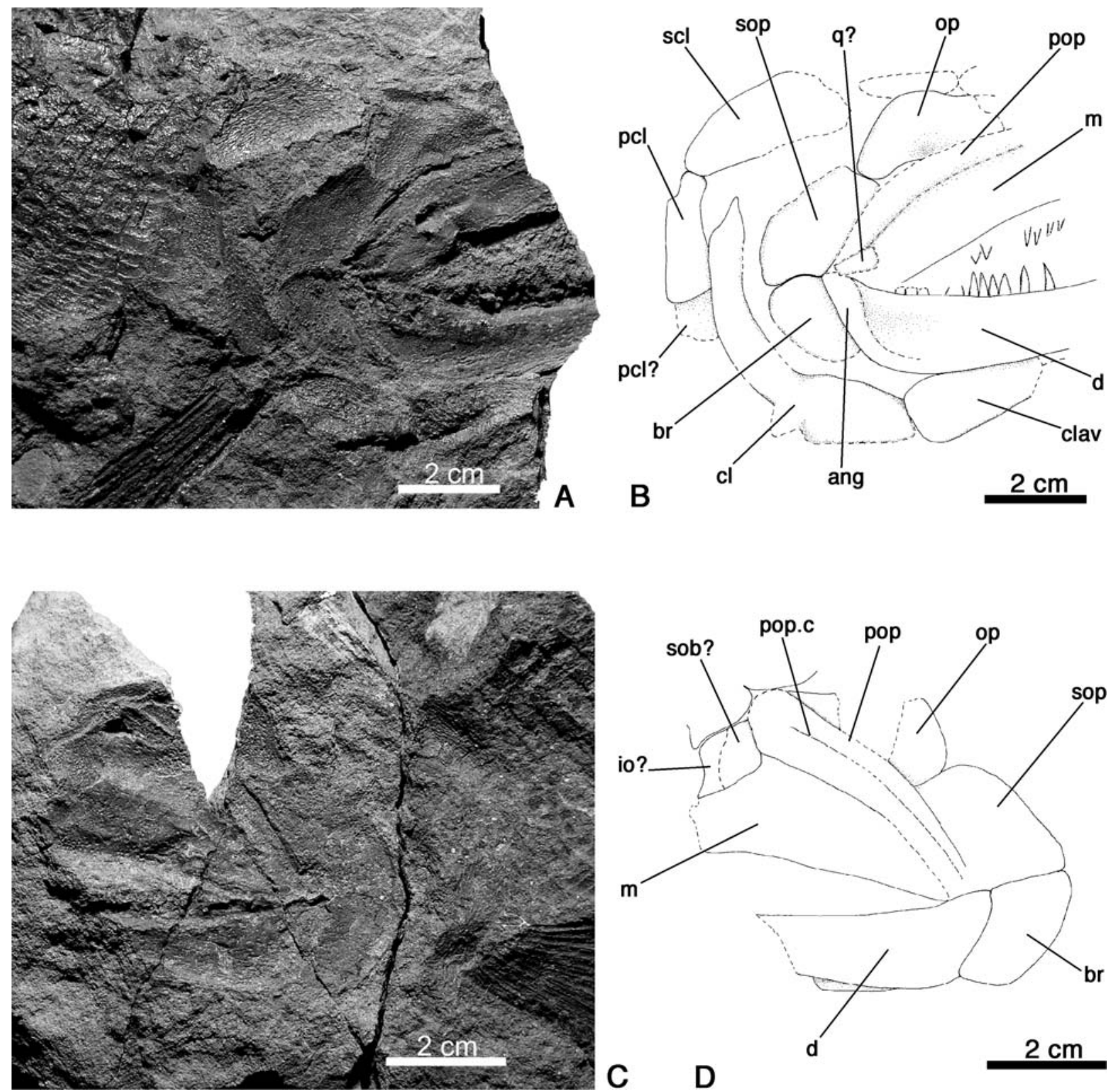

Fig. 5. Rastrolepis riojaensis n. gen. $n$. sp. Skull: $\mathbf{A}$ - photograph of the skull in right lateral view (PULR 103A); B - outline drawing of the skull in PULR 103A; C - photograph of the skull in left lateral view (PULR 103B); D - outline drawing of the skull in PULR 103B. Abbreviations: ang - angular; br - branchiostegal bone; cl - cleithrum; clav - clavicle; d - dentalosplenial; io? - infraorbital bone?; m - maxilla; op - operculum; pcl - postcleithrum; pcl? - postcleithrum?; pop - preoperculum; pop.c - preopercular canal; qj? - quadratojugal?; scl - supracleithrum; sob? - suborbital bone?; sop - suboperculum.

illa. There is no coronoid process. Very large conical marginal teeth are preserved on the dentalosplenial and the maxilla.

The opercular series is remarkably narrow. The operculum and suboperculum are about the same size, the first being slightly deeper, but narrower than the second. The exact shape of the operculum is unknown, but it seems to have narrowed dorsally and ventrally in anterodorsal and posteroventral directions. The posterodorsal border of the suboperculum is broken. However, its outline can be approximated; it is subrectangular, and 1.7 times deeper than wide. The subopercu- lum articulates ventrally with a large, platelike branchiostegal element, at the level of the dorsal border of the angular. The branchiostegal plate is almost as large as the suboperculum, subrectangular, about two times deeper than wide, with slightly rounded posteroventral contour. No remains or traces of other branchiostegal elements are preserved and thus, this branchiostegal plate was probably single.

The ornamentation of the skull bones is not well preserved, but it apparently consisted of tubercles, which were more abundant and smaller on the preoperculum, operculum, suboperculum, 
and branchiostegal plate, than on the maxilla and dentalosplenial. Ventrally and posteriorly, the dentalosplenial is apparently ornamented with rugae, as is the angular.

Pectoral girdle - The dermal bones of the pectoral girdle are displaced. They are ornamented with thin irregular rugae (Fig. 5A, B). The supracleithrum is large, about 2.8 times deeper than long and approximately as long as, but 1.3 times deeper than the suboperculum. It widened dorsally, and although the dorsal border is broken off, it seems to have narrowed again in an anterodorsal direction. There is at least one large postcleithrum preserved. It is subrectangular, narrowing dorsally, with a distinct dorsal articular portion. Ventral to this postcleithrum is a fragmented bone indicating the possibility of a second postcleithrum, but there is no certain evidence for this bone. The cleithrum is a generally slender, elongate, anteriorly curved and dorsally pointed bone. Its anteroventral portion is not only wider than its dorsal part, but apparently more robust as well. A posteroventral cleithral process is probably present. The clavicle is large and approximately oval-shaped.

Paired fins - The pectoral fins are large, forming a wide web, and their length is about $77 \%$ of the maximum height of the body, and about $23 \%$ of the CT length (Fig. 4). There are at least 13 wide, only distally segmented and bifurcated rays. The leading edge is bordered by more than 80 slender fringing fulcra. The fringing fulcra are supported by the first four rays, but are not interspersed by their terminal joints.

The pelvic fins are approximately midway between the pectoral and the anal fins, only slightly closer to the anal (Fig. 3). Only the left pelvic fin is partially preserved and its origin is at about $34 \%$ of the CT length. The fin web is very poorly preserved, but numerous small and slender fringing fulcra are clearly visible on the preserved portion of the leading edge. The rays are evenly segmented starting at their bases and ornamented with a single median ridge.

Unpaired fins - The single dorsal fin originates at about $64 \%$ of the CT length, at the same level of the origin of the anal fin (Fig. 4). The distal ends of the dorsal and anal fin rays are not preserved, but both fins are approximately triangular and of similar size, being both deeper than long and relatively small. Their bases are about $45 \%$ of the maximum height of the body and about $13 \%$ of the CT length. Both dorsal and anal fin rays are ornamented with a median longitudinal ridge, parallel to the axis of the ray.
The dorsal fin (Fig. 6A) is preceded by three small and slender basal fulcra, the first of which is very short. They are followed by approximately 20 lepidotrichia (the posteriormost rays are not well preserved). All of the preserved rays are evenly segmented starting at their bases and except for the anteriormost ones they are also distally branched. The anteriormost four rays are not branched and their length abruptly increases backwards, participating in the leading edge of the fin. They bear fringing fulcra on their distal portions. The following ray also participate in the leading edge of the fin, but it bifurcates once, bearing fringing fulcra on the distal portion of each branch. The distal ends of these leading rays intercalate in between the fringing fulcra.

The leading edge of the anal fin (Fig. 6B) is only preserved distally, where fringing fulcra are present on the distal end of two apparently unbranched rays. In this case, and differing from the dorsal fin, the distal end of the bearing ray does not intercalate in between the fringing fulcra. About 26 lepidotrichia are preserved, which might be close to the total number of rays since only the anteriormost ones are missing. All of them are evenly segmented starting at their bases and, except for those that participate in the leading edge, they are distally bifurcated. The origin of the fin is not preserved and it is thus not possible to know whether basal fulcra were present or not.

The caudal fin is hemiheterocercal, with a well developed, posteriorly rounded scaly lobe (Fig. 6C). Only the bases of the caudal fin rays are preserved and thus the shape of the fin is unknown. There are about 43 rays. According to the orientation of the scales on the scaly lobe, about $5-6$ of these rays are in epaxial position. The fin is preceded by a series of relatively small dorsal and ventral median scutes, not much larger than the normal caudal scales, the total number of which cannot be determined. There are about four very slender dorsal basal fulcra, but no ventral basal fulcrum is preserved. The ventral border of the fin is poorly preserved, but some small fringing fulcra are visible at the ventral edge. The caudal fin rays are ornamented with several longitudinal ridges.

Squamation - The scales are not well preserved. No ornamentation of the scales is visible, but this might be due to the poor preservation. Similarly, the borders of the scales are always broken so it is not possible to know if they were smooth or not, and the presence of peg and 

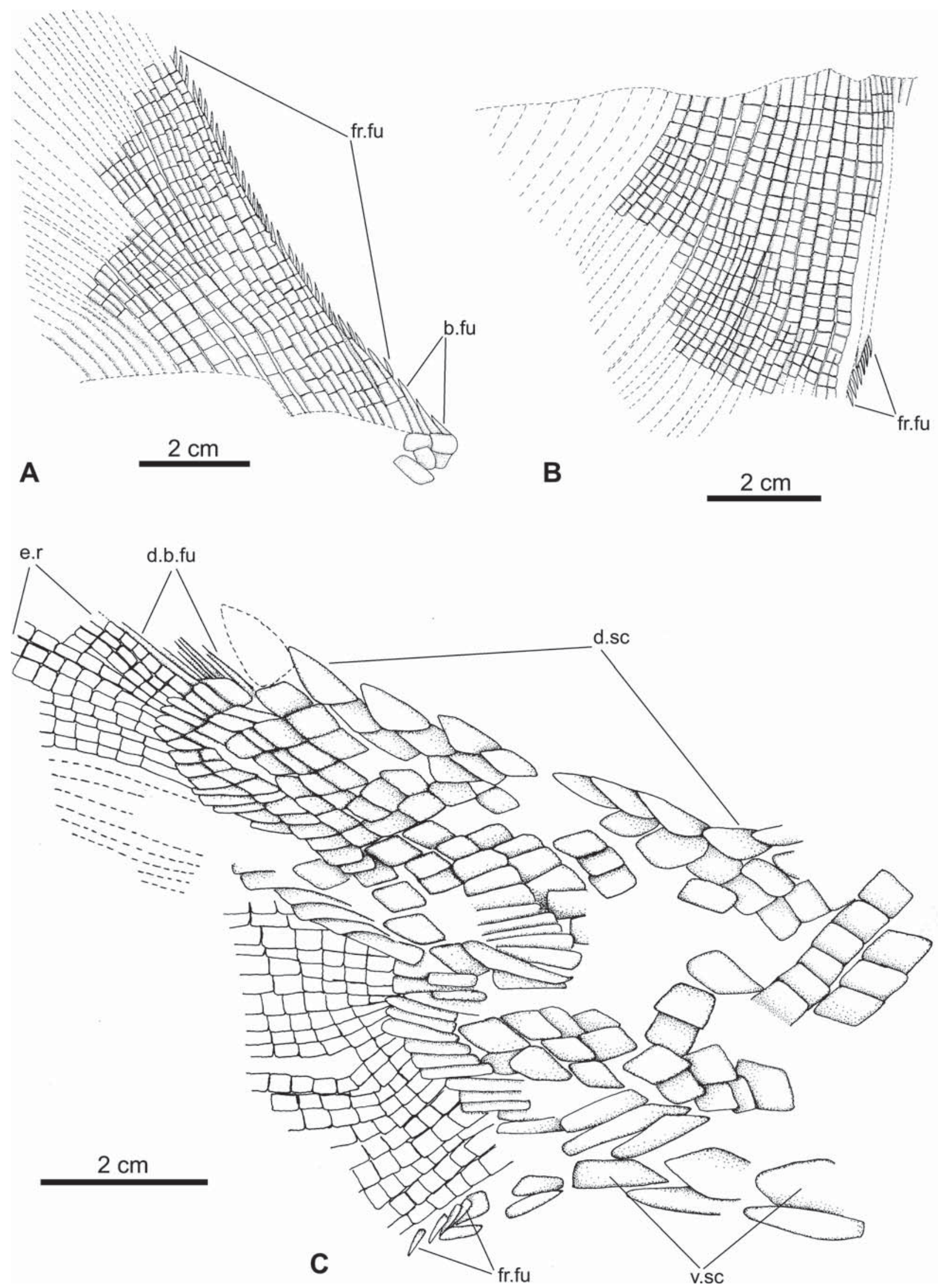

Fig. 6. Rastrolepis riojaensis n. gen. n. sp. Unpaired fins (holotype, PULR 103A): A - dorsal fin; $\mathbf{B}$ - anal fin; C - caudal fin. Abbreviations: b.fu - basal fulcra; d.b.fu - dorsal basal fulcra; d.sc - dorsal scutes; e.r - epaxial caudal fin rays; fr.fu - fringing fulcra; v.sc - ventral scutes. 
socket articulations cannot be evaluated. The flank scales are rectangular in shape, about $30 \%$ longer than deep. They became quadrangular up to slightly deeper than longer dorsally, but much shallower ventrally (e.g. $75 \%$ longer than deeper). Indeed, very shallow scales distinctively cover the ventral region especially in front of the pelvic fins. The scales became rhomboidal on the caudal peduncle and especially on the scaly lobe. A hinge line is apparently present at the level of the anteriormost dorsal median scute of the caudal peduncle (Fig. 6C). The scales on the scaly lobe are generally oriented with their long axis in a posterodorsal direction, except for those that bordered the posteroventral edge. These scales are more slender and oriented with their long axes following the axes of the rays with which they are associated.

\section{Rastrolepis latipinnata n. sp.} Figs $7-8$

\footnotetext{
Derivation of name. For "latus" (Latin), broad, and "pinna" (Latin), a fin, referring to the characteristics of the unpaired fins, much broader in this species than in $R$. riojaensis.
}

Holoty pe. PULR 105A, 105B and 105C. Only specimen.

Type locality. Vicinity of Cañón del Gualo (S: $29^{\circ} 53^{\prime} 38.3^{\prime \prime}$, W: $67^{\circ} 46^{\prime} 21.2^{\prime \prime}$ ), La Rioja province, Argentina (Fig. 1).

Formation and age. Los Rastros Formation (Ladinian), Bermejo Basin, fifth lacustrine hemicycle (see Rogers et al. 2001) (Fig. 2).

Diagnosis. The following diagnosis is based on a unique combination of characters. Almost vertical suspensorium; large pterygoid with a series of anteroventrally converging ridges; lower jaw relatively very large and semilunar in shape; branchiostegal plate about 0.75 times the depth of suboperculum, and of comparable width; suboperculum tearshaped; rectangular supracleithrum about 4 times deeper than wide, about 1.3 times the depth, but 0.6 times the width of the suboperculum; dorsal fin slightly anterior to anal fin; anal fin with about 41 rays, the length of its base being $16 \%$ of the distance between cleithrum and end of scaly lobe; caudal fin hemiheterocercal with about 60 rays; pterygial formula:

\section{$\frac{\mathrm{D} 42}{\mathrm{P} 19 \mathrm{~A} 38 \mathrm{C} 60}$ T63}

Description. Rastrolepis latipinnata is a fusiform elongated fish of more than $540 \mathrm{~mm}$ length (total length of the fossil). The total length of the fish might have been more than $570 \mathrm{~mm}$. The length from the posterior border of the cleithrum to the end of the scaly lobe of the tail (CT length) is $385 \mathrm{~mm}$. The estimated head length is about $100 \mathrm{~mm}$, which is about $18 \%$ of the estimated total length. The maximum height of the fossil, between the pectoral and pelvic fins, is about $140 \mathrm{~mm}$, which is around $36 \%$ of the estimated total length. The height of the body at the origin of dorsal and anal fins is about $90 \mathrm{~mm}$. The passage of the lateral line cannot be discerned. The body is covered with rhombic scales, which vary in size and shape, not only in longitudinal, but also in vertical directions. Small and numerous fringing fulcra are clearly visible in all fins with the exception of the pectorals and the ventral edge of the caudal, which are not preserved. The imperfect preservation of the specimen does not allow to decide about the presence of ganoine in any part of the body.

Skull - The head is incompletely preserved. Only parts of the skull roof, neurocranium, the lower jaw, and two opercular elements are present (Fig. 7). The anterior part of the skull is displaced posteriorly and thus, the posterior elements are not preserved or indistinguishable below the anterior ones. The left parietal (= frontal) is preserved. It is longitudinally elongated, anteriorly expanded and with a supraorbital constriction. There is a longitudinal groove, probably for the supraorbital sensory canal, along the parietal, apparently closer to the median suture between the parietals than to the lateral border of this bone. Size and shape of the postparietal (= parietal) are unknown; the postparietal also has a groove so that the supraorbital sensory canal enters the postparietal. A large left posttemporal is partially preserved posteriorly. Ventral to the temporal region, a handle-like bone probably represents the dorsal portion of the left hyomandibula. The right quadrate, or quadrate portion of the right palatoquadrate, is partially preserved in articulation with the lower jaw. The orientation of the hyomandibula and quadrate indicate an almost vertical suspensorium. A large irregularly shaped bone attached to the left palatoquadrate anteriorly probably represents a modified pterygoid. It is longitudinally elongated and presents a series of posterodorsally directed ridges, which converge anteriorly. Anterior to this pterygoid, a bone with an anteromedially directed handle-like process probably represents the autopalatine portion of the palatoquadrate. Dorsal to this latter bone, a median element with two lateral articulatory surfaces probably represents a median vomer or an ethmoidal ossification.

The relatively very large right lower jaw is preserved in medial view. Individual elements cannot be distinguished. Along the anteroventral 

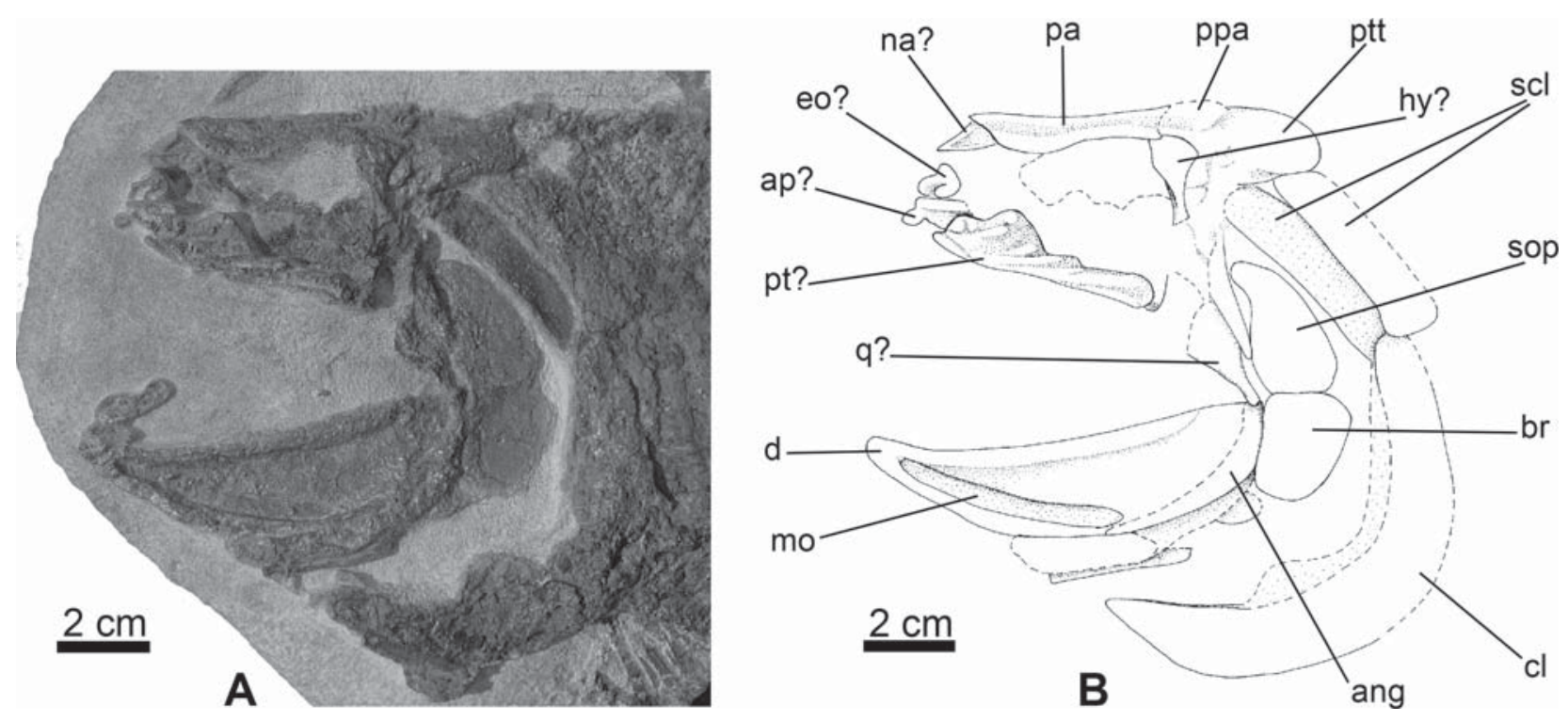

Fig. 7. Rastrolepis latipinnata n. gen. n. sp. Left lateral view of the skull in PULR 105A (holotype): A - photograph; B - outline drawing. Abbreviations: ap? - autopalatine portion of palatoquadrate?; ang - angular; br - branchiostegal bone; cl - cleithrum; d - dentalosplenial; eo? - ethmoidal ossification?; hy? - hyomandibula?; mo - Meckelian ossification; na? - nasal?; pa - parietal; ppa - postparietal; pt - pterygoid; ptt - postemporal; q-quadrate portion of palatoquadrate; scl - supracleithrum; sop - suboperculum.

border of the medial surface, a very thin and elongated ossification probably represents the Meckelian bone. The general shape of the lower jaw is semilunar, with a slightly concave medial surface. Its maximum depth is about 0.3 of its length. There is no coronoid process. No teeth or tooth sockets are preserved.

Two bones are preserved in the opercular region. The most ventral of these bones articulates directly at the level of the lower jaw and presents an anteroventral process running anteroventrally to the lower jaw, so it is interpreted as a large, plate-like branchiostegal bone. Other branchiostegal elements are not preserved. The branchiostegal plate is quadrangular, about 1.25 times deeper than wide. The bone dorsal to it is interpreted as a suboperculum. It is about 1.35 times deeper than the branchiostegal plate, but both elements have approximately the same width. The suboperculum is somewhat tearshaped, with rounded ventral borders narrowing dorsally. Its maximum width is about 0.5 of its depth.

Pectoral girdle - Only the left and right supracleithra of the pectoral girdle are well preserved. Each supracleithrum is approximately rectangular, about 4 times deeper than long, 1.3 times deeper than the suboperculum, but 0.6 times the length of that bone. The cleithrum, or cleithrum and clavicle, form a narrow, deeply curved arch at the posteroventral corner of the head. Postcleithral bones are apparently absent. No ornamentation is preserved.
Paired fins - The pectoral fins are very poorly preserved. At least some pectoral fin-rays carry three parallel longitudinal ridges.

The pelvic fins are slightly closer to the anal than to the pectoral fins, originating at about $35 \%$ of the CT length. The pelvic fin is incompletely preserved and the total number of fin rays is unknown. However, the anterior portion of the fin is well preserved. There are three small basal fulcra and numerous small fringing fulcra on at least the first four rays, which are unbranched and with their distal segments intercalating in between the fringing fulcra. All preserved rays are evenly segmented from their bases, and except for the ones participating on the leading edge of the fin, they are also distally bifurcated.

Unpaired fins - The single dorsal fin at about $60 \%$ of the CT length, slightly anterior to the origin of the anal fin. Both dorsal and anal fin rays carry a median longitudinal ridge parallel to the axis of the ray.

Ten lepidotrichia are preserved in the dorsal fin, but the total number of rays was certainly larger as indicated by a posterior dorsal fin ray separated by a gap from the others. Except for the anteriormost rays, the rays are evenly segmented starting at their bases and distally branched. At least nine lepidotrichia participate on the leading edge of the fin bearing small and slender fringing fulcra. There are two very small, unpaired basal fulcra at the base of the dorsal fin. They are followed by one very short first unbranched ray, that apparently bears no fringing 
fulcrum. The second to fourth rays are also unbranched and still short, their height increasing slowly posteriorly, and bear one fringing fulcrum each. The fifth ray is unbranched, and bears three fringing fulcra. The following four rays also participate in the leading edge of the fin, but they bifurcate, bearing fringing fulcra on the distal end of each branch. The distal ends of these marginal rays intercalate in between the fringing fulcra.

The anal fin is almost completely preserved. The base of the anal fin is about $16 \%$ of the CT length. The fin web consists of 41 lepidotrichia and two most anterior elements that are not well enough preserved to decide whether they represent basal fulcra or fin rays. The lepidotrichia are evenly segmented starting at their bases and, except for the most anterior rays, they were distally bifurcated. At least five rays participate in the leading edge of the fin, which is not preserved distally. The first three rays are segmented but unbranched, and it cannot be decided whether they bear fringing fulcra. The fourth ray bifurcates once and all rays bifurcate more than once from the fifth ray backwards. As is the case in the dorsal fin, the distal segments of the leading rays intercalate in between the fringing fulcra.

The caudal fin, as indicated by a hinge line, is hemiheterocercal with a short and rounded scaly lobe (Fig. 8A). A few slender, posterodorsally oriented bones in the tail of PULR 105B, might represent endoskeletal elements of support or the most basal portion of the fin-rays, which would have been covered with soft tissues and scales in the living fish (Fig. 8B). The shape of the fin web is unknown, but includes approximately $60 \mathrm{seg}$ mented rays. In this fin, the basal segment is two or three times longer than the following ones. The basal segment of one ray is Y shaped, giving off two very early branches of the ray. There is a very small, unpaired basal fulcrum at the dorsal base of the caudal fin (Fig. 8B). Immediately behind, the first ray is very short, unbranched, bears two small and slender fringing fulcra. The following two rays are also unbranched and bear fringing fulcra (Fig. 8A, B). The fourth ray branches once, and the fifth twice and bear fringing fulcra on each branch. The sixth ray branches three times symmetrically and bears fringing fulcra at least on the most marginal branch (the distal end of this ray is not preserved). The ventral border of the fin is not preserved, so that the presence of ventral basal or fringing fulcra cannot be established. Each of the caudal finrays carries a single longitudinal ridge (Fig. 8B).
Squamation - The scales are poorly preserved and ganoine is not preserved, but it was probably present. There are about 63 vertical rows of scales. The scales are rectangular, with smooth posterior border. The scales are regularly two times longer than deep on the flank, including the scales immediately behind the pectoral girdle, and in the caudal peduncle. A series of small dorsal ridge scales garnishes the dorsal midline between the skull and the dorsal fin, and immediately before the caudal fin (Fig. 8A). There is a hinge line at the base of the scaly lobe of the tail, where the scales are smaller, quadrangular or even slightly deeper than long.

Acrolepidae Aldinger, 1937

\section{Challaia Rusconi, 1946}

\section{Challaia elongata (Cabrera, 1944) n. comb.}

Figs 9-12

1944 Myriolepis elongatus [sic] Cabrera: 574, fig. 4 (original description).

Holoty pe. MLP 44-VII-16-3.

Type locality. Agua de La Peña Creek, San Juan province, Argentina.

Formation and age. Los Rastros Formation (Ladinian), Bermejo Basin.

Diagnosis. The following diagnosis is based on a unique combination of characters. Large actinopterygian with fusiform body attaining an estimated total length of 700-800 mm; maxilla with large, trapezoidal postorbital plate with subtriangular posteroventral expansion overlapping lower jaw; preoperculum very inclined and narrow with short anterodorsally directed process; one elongated dermohyal; 3 anteopercular bones; operculum narrowing upwards, 2 times deeper and 0.9 times narrower than suboperculum; suboperculum as wide as first branchiostegal plate; long and narrow supracleithrum, 4 times deeper than wide, about 1.5 times deeper and 0.5 narrower than operculum; lower jaw relatively shallow, slender, tapering anteriorly; two types of conical teeth, one large and sharp, the other small and rounded; pectoral fin lepidotrichia with proximal segments 4 times longer than following segment, which is 1.5 times longer than remaining segments; pelvic fin rays evenly segmented starting at their bases and ornamented with oblique ganoine ridges; numerous, slender fringing fulcra on pelvic fin; anterior flank scales rectangular, $38 \%$ deeper than long, quadrangular posteriorly, longer than deep dorsally and ventrally, ornamented with $10-16$ posteroventrally directed ganoine ridges irregularly anastomosing posteriorly, not reaching posterior margin of scale; approximate pterygial formula:

$$
\frac{\mathrm{D} 78}{\mathrm{P} 37 \mathrm{~A} ? \mathrm{C} ?} \mathrm{~T}>100
$$

Referred specimen. PULR 104, from the fifth lacustrine hemicycle of Los Rastros Formation in the vicinity of Cañón del Gualo $\left(29^{\circ} 53^{\prime} 38.3^{\prime \prime}\right.$ S, $\left.67^{\circ} 46^{\prime} 21.2^{\prime \prime} \mathrm{W}\right)$, La Rioja province, Argentina. 

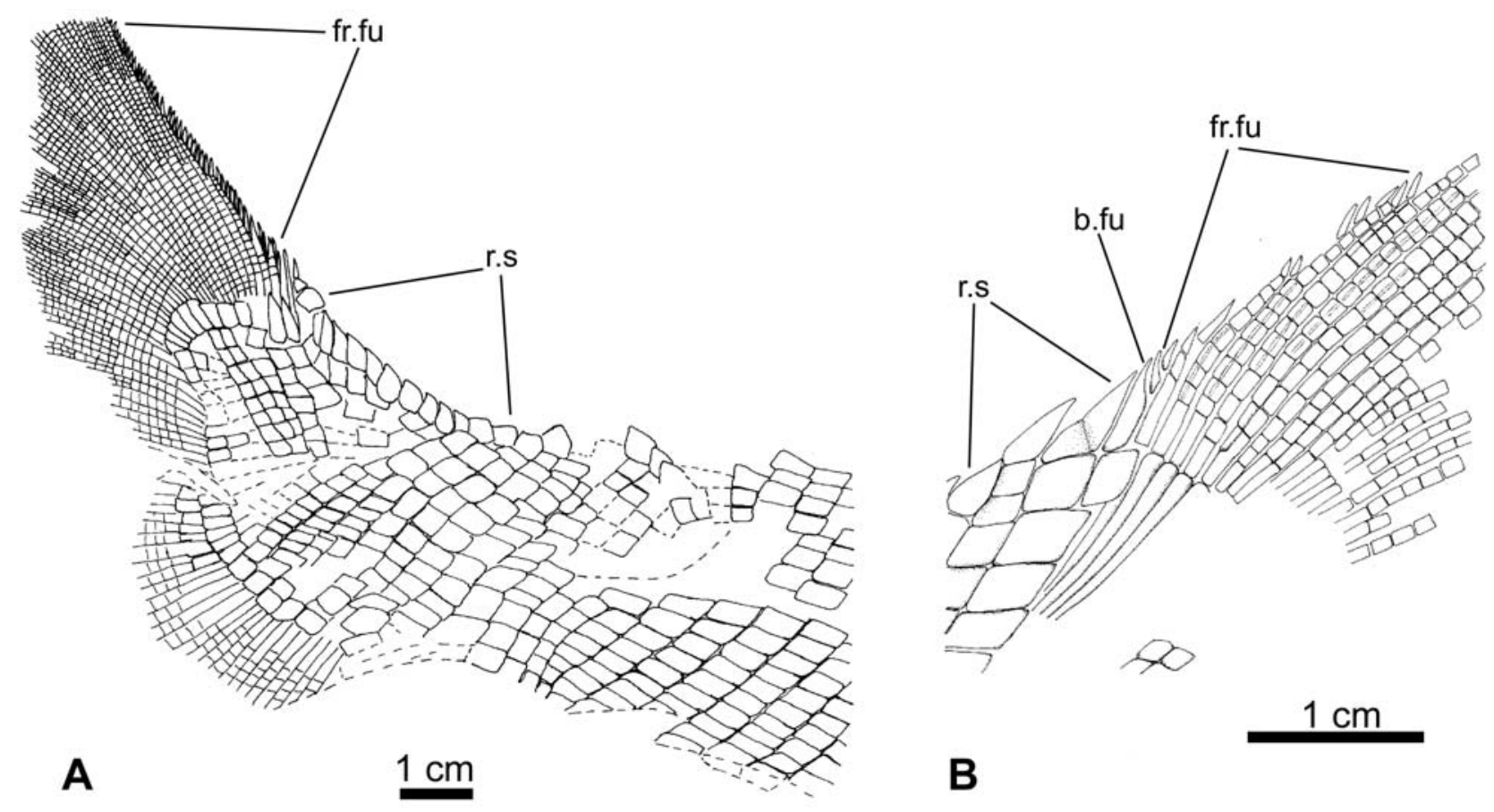

Fig. 8. Rastrolepis latipinnata n. gen. n. sp. Caudal fin: A - PULR 105B (holotype); B - detail showing the exposed basalmost fin-ray segments or endosqueletal supports in PULR 105C (holotype). Abbreviations: b.fu - basal fulcrum; fr.fu - fringing fulcra; r.s - ridge scales.

D e s crip ti o n. In the holotype (MLP 44-VII-16-3), only the anterior portion of the fish, without caudal peduncle and tail, is preserved. The anterior part of the head is missing as well as most of the pectoral and dorsal fins. The pelvic fins are partially preserved. Only the origin of the dorsal fin is preserved and there are no remains of the anal and caudal fins. Although the preservation of the scales is rather poor, their shape and ornamentation, and the squamation pattern can be inferred. The referred specimen (PULR 104) consists of a very poorly preserved skull and

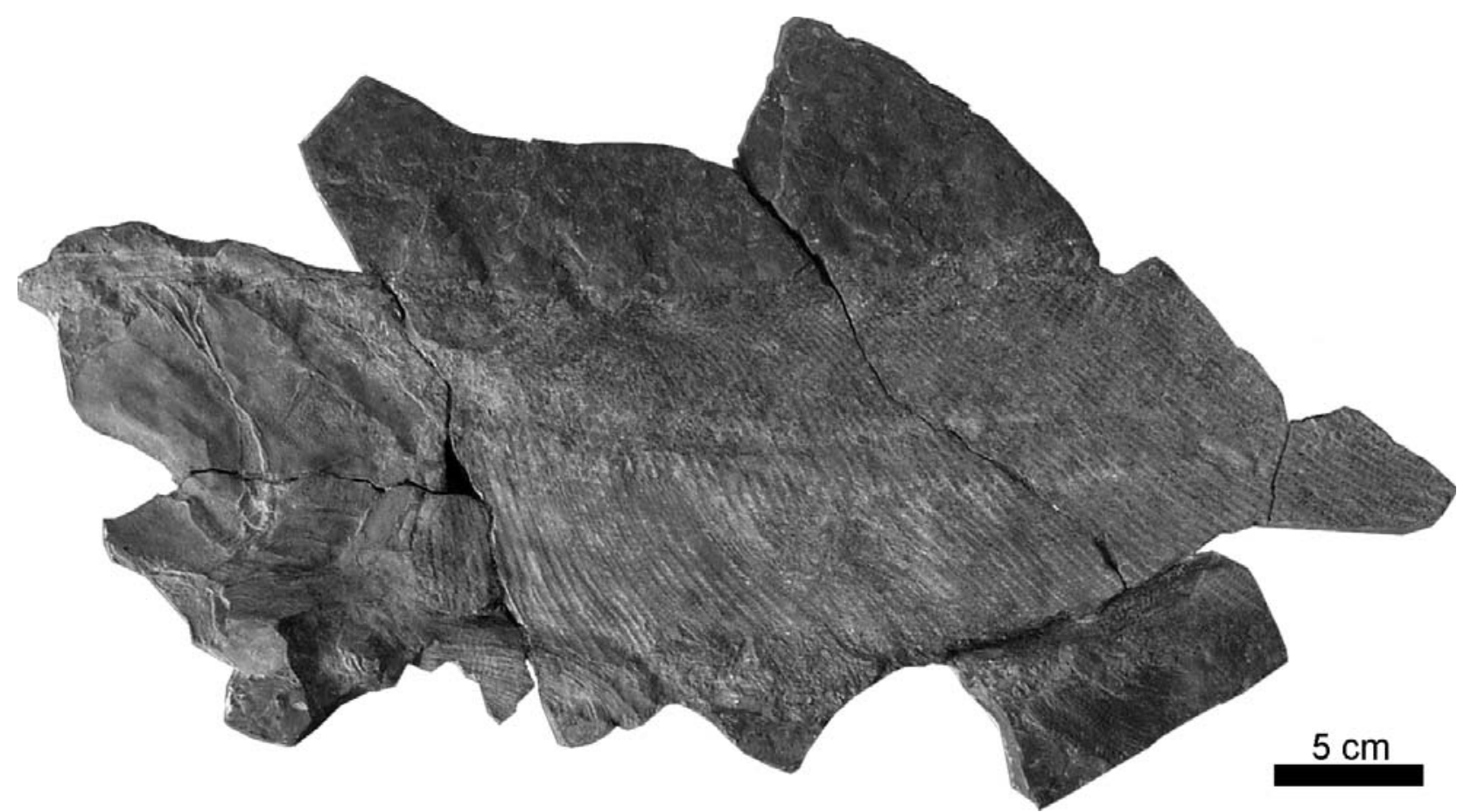

Fig. 9. Challaia elongata (Cabrera, 1944) n. comb. Left lateral view of MLP 44-VII-16-3 (holotype). 
anterior part of the body without fins, but it preserves much better the characteristic ornamentation of the scales.

The fish is more than $480 \mathrm{~mm}$ length (total length of the holotype). The real proportions of the head and tail are unknown, but the total length of the fish might have been around 700$800 \mathrm{~mm}$. The general body form is fusiform and elongated (Fig. 9). The preserved portion of the trunk seems to be slightly compressed dorsoventrally, but the body is apparently as deep as the head, which would have been about $20 \%$ of the minimal estimated total length. The bones of the dermal-skull and pectoral girdle are ornamented, but ganoine is not preserved. The body is covered with numerous, relatively small ganoid scales, which vary in size and shape, not only in longitudinal, but also in vertical directions.

Skull - The skull is only partially preserved in both specimens so that the complete anatomy of the skull cannot be reconstructed.

Only the large postorbital plate of the maxilla is preserved in the holotype. It is deep and subrectangular, approximately 2 times longer than deep (Fig. 10B). There is a somewhat triangular posteroventral expansion of the maxilla overlapping the lower jaw. PULR 104 shows poorly preserved remains of the suborbital portion of the maxilla, which is apparently very narrow. The lower jaw is almost completely preserved in PULR 104. It is slender, tapering anteriorly, extending probably beyond the anterior tip of the maxilla. Its maximum depth is about $20 \%$ of its length. There is no coronoid process. The dentition is partially preserved in both specimens. Both maxilla and dentalosplenial carry two kinds of marginal teeth, probably arranged in two rows. There are remains of very large, sharp and powerful conical teeth, accompanied with smaller, also conical ones (Fig. 11).

The preoperculum is very inclined indicating a very oblique suspensorium (Fig. 10). Although it is very narrow, it is possible to distinguish an anterior and a ventral arm. The maximum depth of the bone, at its anterior end, is about 0.5 times the depth of the postorbital plate of the maxilla. The depth of the anterior arm decreases posteroventrally until it bends slightly into the ventral arm, which is ventrally widening. There is a short anterodorsally directed process at the anterodorsal corner of the preoperculum.

Three bones are preserved posterior to the preoperculum and dorsal to the operculum (Fig. 10). The anteriormost of these bones is interpreted as a dermohyal. It is dorsoventrally elongated, with a rounded dorsal border and ventrally tapering. The dermohyal articulates with about $60 \%$ of the posterior border of the dorsal arm of the preoperculum anteriorly, with the supratemporal dorsally, and with the anterior anteoperculum and operculum posteriorly. The two bones posterior to the dermohyal and dorsal to the operculum are interpreted as anterior and posterior anteoperculae. Together they occupy a
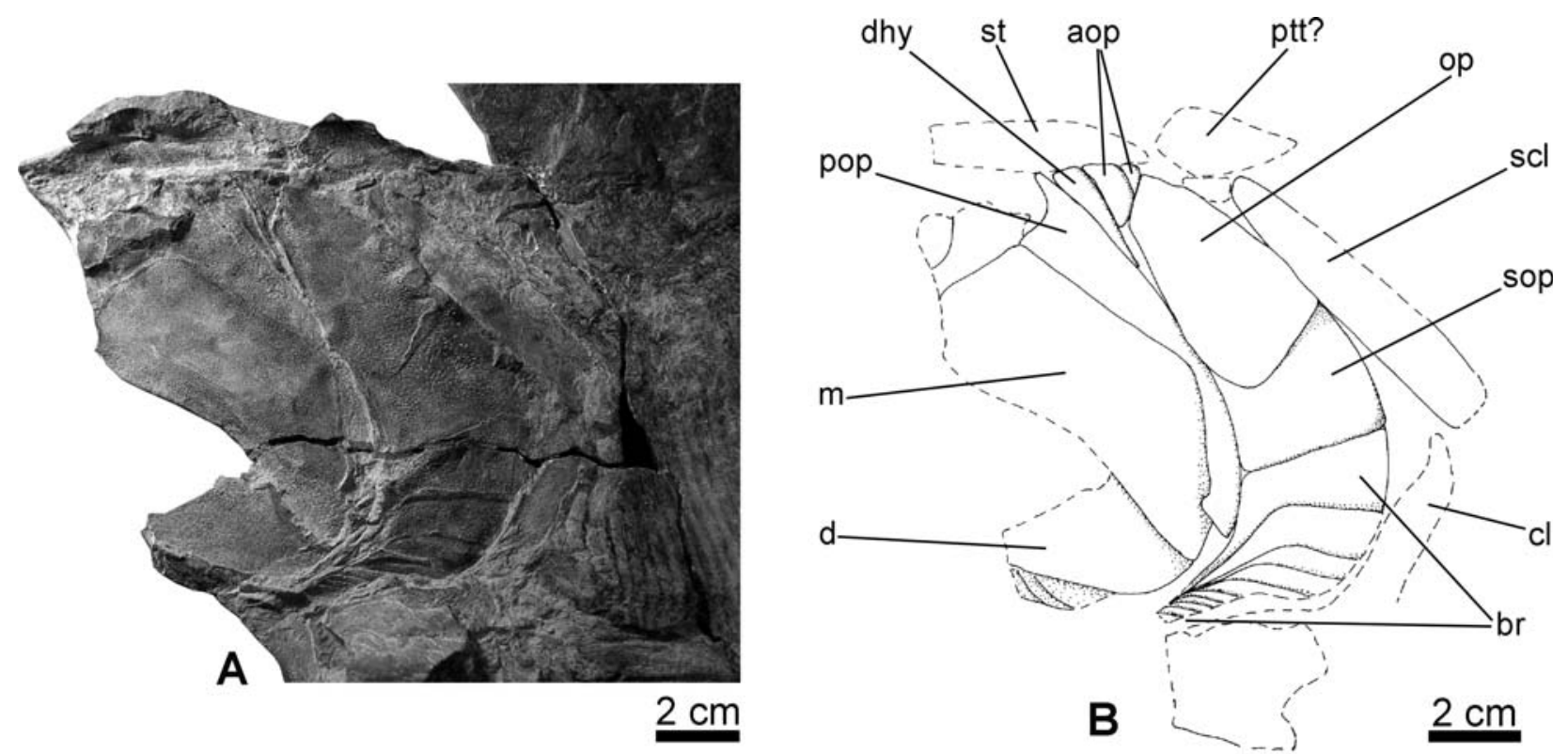

Fig. 10. Challaia elongata (Cabrera, 1944) n. comb. Left lateral view of the skull in MLP 44-VII-16-3 (holotype): A - photograph; B - outline drawing. Abbreviations: aop - anteoperculars; br - branchiostegal rays; cl - cleithrum; d - dentalosplenial; dhy - dermohyal; m - maxilla; op - operculum; pop - preoperculum; ptt? - postemporal?; scl - supracleithrum; sop - suboperculum; st - supratemporal. 
triangular area and articulate with the dermohyal anteriorly, the supratemporal dorsally and the operculum posteroventrally. The anterior anteoperculum is the largest and trapezoidal in shape, and the posterior anteoperculum is small and triangular.

The operculum is relatively narrow, trapezoidal, and narrowed upwards (Fig. 10). Its ventral portion overlaps the suboperculum. It is two times deeper than wide, with a maximum width about 0.9 times the width of the suboperculum and slightly less than the maximum depth of the postorbital plate of the maxilla. The suboperculum is also approximately trapezoidal. The maximum depth of its exposed portion is about half the depth of the operculum, and as wide as the first and widest branchiostegal ray. Only nine branchiostegal rays are represented in the holotype, ventral to the suboperculum and posterior to the jaws. The specimen PULR 104 shows eight branchiostetgal rays ventral to the lower jaw and the total number of branchiostegal rays was probably around 17 .

The ornamentation of the skull bones is preserved in the holotype as an imprint and thus, it can be inferred. The operculum is ornamented with numerous, short, thin, and anastomosing irregular rugae distributed all over the lateral surface of the bone, without following any particular pattern. The suboperculum is ornamented in a very similar way, with the same kind of rugae over most of its lateral surface, but the rugae are gradually smaller towards the anteroventral corner where densely placed, small tubercles are present. The branchiostegal rays are densely ornamented with small tubercles, similar to those on the suboperculum. The preoperculum is ornamented with similar kind or rugae and tubercles, irregularly and densely distributed over the whole lateral surface of the bone. The ornamentation of the dermohyal and anteoperculum cannot be inferred with certainty, but it seems to have been similar to that of the preoperculum. As far as known from the preserved portions of these bones, the ornamentation of the maxilla and dentalosplenial consists of very small tubercles, regularly and very densely distributed over the whole lateral surface.

Pectoral girdle - The dermal bones of the pectoral girdle were certainly ornamented, but in this case the ornamentation pattern cannot be established clearly. At least the posttemporal seems to have been ornamented with delicate, very densely placed, approximately parallel rugae covering its lateral surface completely.
The posttemporal is incompletely preserved, but it is apparently of triangular shape, with a posteriorly projected posteroventral corner (Fig. 10). The supracleithrum is relatively large, long and narrow. It is about 4 times deeper than wide, and 1.5 times the height and half the maximum width of the operculum. The shape of the bone is elliptically elongated, slightly narrowing dorsally. The cleithrum is incompletely preserved. No postcleithrum can be distinguished and these bones were probably absent.

Paired fins - The pectoral fins are very poorly preserved (Fig. 9). Their insertion is very low, at the ventral margin of the flank. The length of the pectoral fin web is about $55 \%$ of the estimated depth of the head. The left pectoral fin is partially preserved in the holotype, with imprints of 26 pectoral fin rays, but the total number of rays was apparently larger. All preserved rays are segmented and distally bifurcated. The proximal segment is about 4 times longer than the following segment, which is about 1.5 times longer than the remaining ones. No ornamentation of the fin rays is preserved. No fringing fulcra is preserved on this fin, but it is not possible to know whether they were present or not.

The pelvic fins are relatively small, but long based (Fig. 9). The origin of the pelvic fin is behind the $37^{\text {th }}$ vertical row of scales and its end at about the $50^{\text {th }}$ vertical row of scales. About 35 pelvic fin rays are preserved as imprints in the holotype and this seems to be close to the total number of rays in the fin. The rays are evenly segmented starting at their bases and ornamented with oblique, parallel ganoine ridges. Numerous delicate, small and slender fringing fulcra are preserved on the leading edge of the pelvic fin, but their total number cannot be established.

Unpaired fins - Among the unpaired fins, only the origin of the dorsal fin is poorly preserved, which is placed behind the $78^{\text {th }}$ vertical row of scales (Fig. 9).

Squamation - The scales are preserved as imprints in both specimens. They are relatively small and numerous; 81 vertical rows of scales are preserved in the holotype and thus, a total of more than 100 vertical rows to the base of the tail is estimated since the whole caudal peduncle or even more is missing. The number of scales on a single vertical row cannot be precisely determined, but there are certainly more than 50 scales on the vertical rows of the flank. The scales on the flank, immediately behind the pectoral girdle, are rectangular, deeper than long (e.g. $5.5 \mathrm{~mm}$ height and $4 \mathrm{~mm}$ length in the holo- 

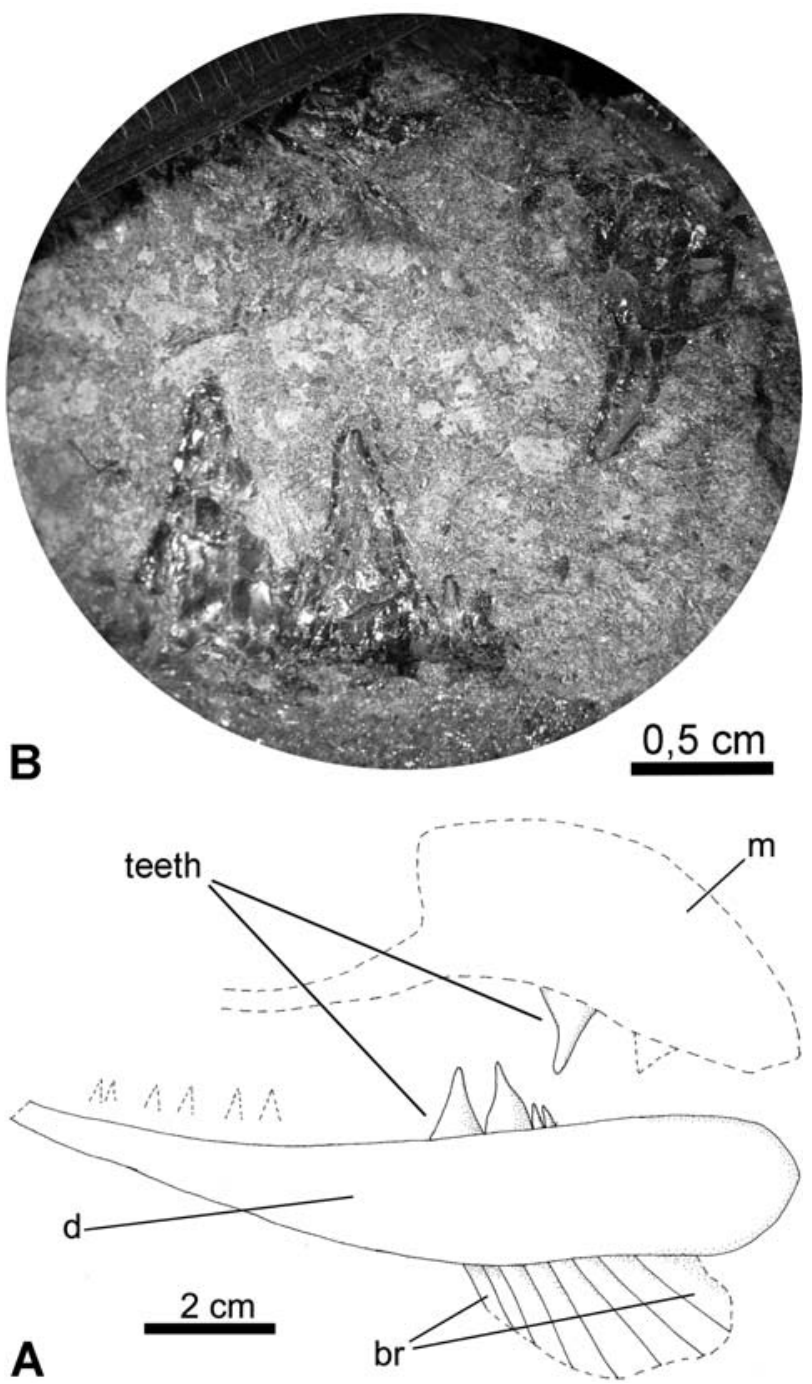

Fig. 11. Challaia elongata (Cabrera, 1944) n. comb. A - outline drawing of the jaws in lateral view in PULR 104; abbreviations: $\quad$ br - branchiostegal rays; $\quad \mathbf{d}$-dentalosplenial; $\mathbf{m}$ - maxilla. B - detailed photograph of the preserved teeth.

type), but they rapidly become quadrangular posteriorly. Both dorsally and ventrally the scales are smaller, mainly shallower, but also slightly narrower so that each transverse row is anteriorly inclined and some additional, incomplete transverse rows of scales are intercalated in between the complete ones ventrally. The scales apparently overlapped each other posteriorly. Peg and socket articulations are clearly preserved on the anterior and ventral regions of the flank in the holotype, but they are not preserved or absent in other parts of the body. Externally, the scales are ornamented with numerous oblique ganoine ridges, irregularly anastomosing posteriorly and not reaching the posterior margin of the scale (Fig. 12). The ganoine ridges are more numerous in the anterior portion of the flank (14-16) than in the abdominal region (6-8). The dorsal and ventral midlines of the body are not well preserved in any specimen. However, a dorsal raw of small ridge scales is partially preserved in both specimens. These ridge scales are of comparable size with those in the flank, and this row seems to have been complete between the skull and the dorsal fin.

Discussion. Challaia elongata (Cabrera, 1944) was originally referred to the Australian genus Myriolepis Egerton, 1864. However, the available information on any of the two species of Myriolepis is very poor, including only features that are also present in other primitive actinopterygian taxa. Challaia elongata shares with $M y r-$ iolepis an overall similarity in the general body form, relative position of the fins, squamation, a very oblique suspensorium, and a large gape and large conical teeth. All of these characters can be found in any acrolepid fish (see below). Furthermore, Ch. elongata differs from Myriolepis in several features. In Myriolepis clarkei Egerton, 1864, the type species of the genus, the operculum is much smaller than the suboperculum, which is of uniform breadth (Woodward 1890). Challaia elongata also differs from M. lata Woodward, 1890, in the general body form, the

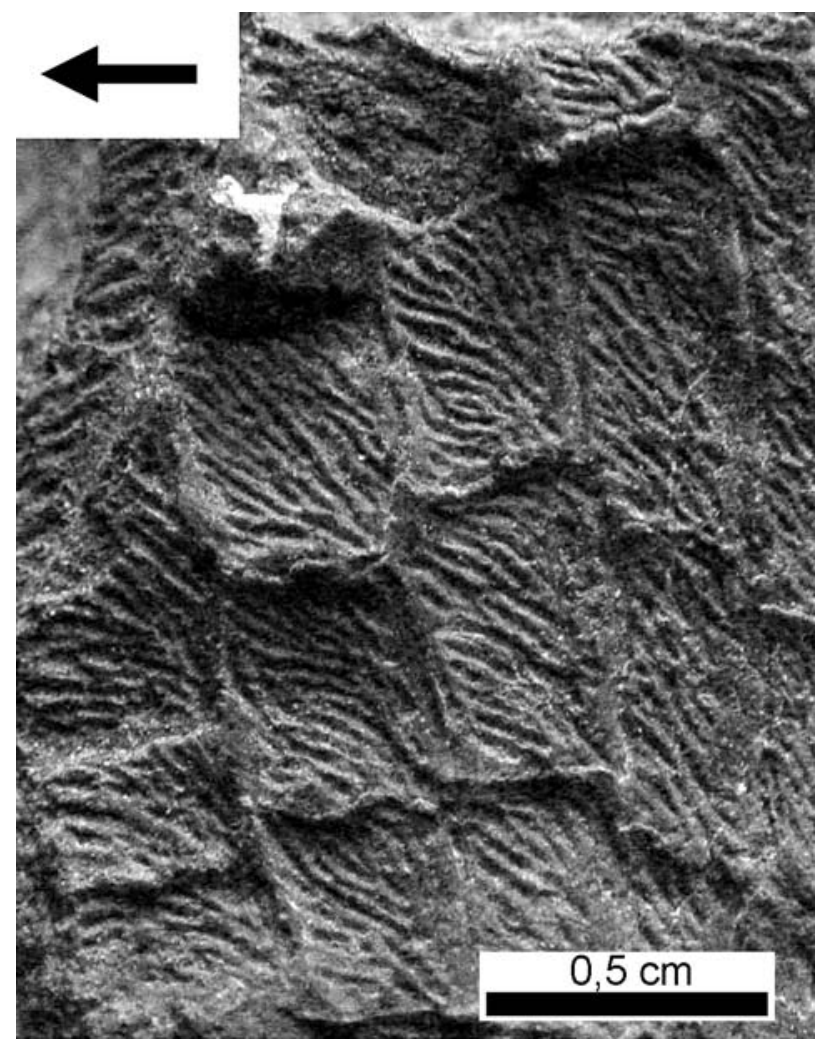

Fig. 12. Challaia elongata (Cabrera, 1944) n. comb. Detailed photograph of the external mould of the anterior flank scales in PULR 104 showing the peculiar ornamentation with numerous oblique ganoine ridges, irregularly anastomosing posteriorly and not reaching the posterior margin of the scale; arrow points anteriad. 
relative size and shape of the preoperculum, opercular bones and branchiostegal rays, and the ornamentation of the jaws (Woodward 1890; Wade 1935). Although poorly known, M. hibernica Traquair, 1893, and M.pectinata Woodward, 1908, also differ from M. elongata. The first of this species is a much smaller fish in which the pelvic fins are small and narrow (Traquair 1893); $M$. pectinata has deepened flank scales, twice as deep as broad (Woodward, 1908). Therefore, in the absence of any distinctive feature supporting the referral of Ch.elongata to Myriolepis, these South American and Australian fishes should be kept as separate taxa.

On the other hand, Challaia elongata closely resembles the species of Challaia, from the Upper Triassic rocks of the neighbor Cuyo Basin. They share a similar squamation and similar shape and proportions of comparable skull bones. Challaia elongata differs from Ch. striata Rusconi, 1946 (MCNAM PV 49), in the ornamentation of the scales. The scales of Ch. striata are also ornamented with ridges, but these are less numerous and proportionally thicker than in Ch. elongata, and they anastomose only seldom. In Ch. magna Rusconi, 1949a (MCNAM PV 2790), the lower jaw is more robust than in Ch. elongata, the posteroventral expansion of the maxilla rounded and the dentition is different, consisting of very large and stout, tightly packed conical teeth. The type and only known specimen of Ch. multidentata Rusconi, 1949b (MCNAM PV 2792), is unfortunately lost and according to the information given by Rusconi it might be a junior synonym of Ch. elongata.

Among basal actinopterygians, Challaia resembles acrolepids (Aldinger 1937) particularly in the characteristics of the scales, which are deeply sculptured with posteriorly to posteroventrally directed ganoine ridges that cover the exposed surface of the scale completely, but do not reach the posterior margin of the scale and variably anastomose posteriorly (Agassiz 1833; Aldinger 1937). Similarly ornamented scales are also found in Howqualepis Long, 1988, Pteronisculus White, 1933, Turseodus Leidy, 1857, Mentzichthys Jubb, 1965, Australichthys Gardiner, 1969, Aestuarichthys Gardiner, 1969, Willomorichthys Gardiner, 1969, Ameghinichthys Arratia et al., 2004, Colobodontidae Andersson, 1916, and Ptycholepidae Brough, 1939. However, the combination of characters described above is unique to the taxa included by Aldinger in Groups $\mathrm{A}$ and $\mathrm{B}$ of the family Acrolepidae (Aldinger 1937: 254). Also, the characteristics of the skull in Challaia clearly differ from colobodontids and ptycholepids. In colobodontids the suspensorium is vertical, the preoperculum has a broad platelike dorsal portion, the operculum is much larger than the suboperculum, and the postorbital portion of the maxilla is relatively much smaller and triangular than in Challaia (Mutter 2002, 2004). In ptycholepids, the suspensorium is also vertical and the opercular bones are relatively wider, and the postorbital portion of the maxilla is relatively smaller than in Challaia (Brough 1939; Nielsen 1942; Wenz 1959; pers. obs.). Therefore, Challaia is tentatively referred to the Acrolepidae, pending a thorough revision of this family, which is beyond the scope of the present paper.

\section{Discussion}

The presently known fossil ichthyofauna of the Los Rastros Formation includes four different taxa (three genera, four species) of basal actinopterygians. The relationships of Gualolepis and Rastrolepis are unknown. Challaia elongata is referred to Acrolepidae. Most acrolepids are known from Paleozoic rocks, but a few members are represented in the Triassic sediments of Grönland (Acrorhabdus, Boreosomus; Aldinger 1937, Nielsen 1842), Europe (Hyllingea; Aldinger 1937) and Australia (Leptogenichthys; Long 1991; probably also Myriolepis). The Triassic acrolepids from Argentina represent the youngest record of the family in Gondwana.

Compared with other Triassic ichthyofaunas of Gondwana, the presently known fish fauna of the Los Rastros Formation appears relatively depauperate (López-Arbarello 2004). However, four species were identified among only five collected specimens from a single fish-bearing stratum in the Cañón del Gualo locality. Given the number of distinct taxa identified in the limited sampling of this apparently very productive horizon, fish diversity in the lakes of the Los Rastros Formation may have been much greater than our current collections suggest. Also, the ichthyofauna of Los Rastros appears different from other known Triassic faunas of Gondwana in the absence of "perleidiforms" (López-Arbarello 2004). "Perleidiforms" are generally small fishes and thus, their absence in the described fish assemblage from Los Rastros Formation may be a preservational bias.

Challaia represents the first fish taxon common to both the Cuyo and the Bermejo basins. 
So far, the only other vertebrate taxon common to both basins is the temnospondyl Pelorocephalus (Marsicano et al. 2001). In the Cuyo basin, Challaia is found in the Potrerillos Formation and the overlying Cacheuta Formation. The correlation between the Potrerillos and Los Rastros formations was already demonstrated on palynological evidence (Zavattieri \& Batten 1996; Morel et al. 2002b). The Cacheuta Formation is dated as Carnian-Norian (Morel et al. 2002a).

Finally, the fossils described in this report are all representative of large predaceous fishes. Mancuso (2003) interpreted these fishes as allochthonous forms that entered the ancient lake from rivers. An equally plausible hypothesis is that the large predaceous fishes described here were inhabitants of the ancient Los Rastros lake environment. Regardless of their inferred preferred habitat, which may have included both rivers and lakes, the fish reported here are definitely of freshwater origin. This is an important distinction because most known Triassic fish faunas are marine in origin.

\section{Acknowledgments}

We thank H.-P. Schultze (University of Kansas, Lawrence, USA) as well as O. W. M. Rauhut and H. Mayr (Bayerische Staatssammlung für Paläontologie und Geologie, München, Germany) for enlightening discussions and valuable advice. The reviewers G. Arratia (University of Kansas, Lawrence, USA) and C. Poplin (Muséum National d'Histoire naturelle, Paris, France), and the editor, D. Korn (Museum für Naturkunde der Humboldt-Universität zu Berlin, Germany) are acknowledged for appropriate criticism and suggestions. The Universidad Nacional de La Rioja, through A. Arcucci (Universidad Nacional de San Luis, San Luis, Argentina), and the Museo de Ciencias Naturales y Antropológicas "Juan Cornelio Moyano" Mendoza gave access to the material. The material was mainly prepared by G. Cándido and R. Agüero (Museo Paleontológico Egidio Feruglio, Trelew, Argentina) but also L. Berner (Museum für Naturkunde der Humboldt-Universität zu Berlin, Germany) helped with the preparation of one of the specimens. G. Janssen (Bayerische Staatssammlung für Paläontologie und Geologie, München, Germany) assisted with the preparation of the photographs. The material was collected in 1995 during fieldwork supported by the National Geographic Society (to C. A. Forster, State University of New York, Stony Brook, USA, and C. L. May, Geological Society of America, Boulder, USA) and the Museo de Ciencias Naturales of the Universidad Nacional de La Rioja. The present study was carried out during postdoctoral fellowships from the Deutscher Akademischer Austauschdienst (DAAD) in Germany, and the Consejo Nacional de Investigaciones Científicas y Técnicas (CONICET) in Argentina to A. López-Arbarello, who is currently supported by the DFG (German Research Foundation) under project LO 1405/1-1.

\section{References}

Agassiz, L. 1833-44. Recherches sur les poissons fossiles. Vol 2, Petitpierre, Neuchâtel.

Aldinger, H. 1937. Permische Ganoidfische aus Ostgrönland. - Meddelelser om Grønland 102 (3): 1-392.

Andersson, E. (= Stensiö) 1916. Über einige Trias-Fische aus der Cava Trefontane, Tessin. - Bulletin of the Geological Institut of Upsala 15: 13-33.

Arratia, G. \& Cloutier, R. 1996. Reassessment of the morphology of Cheirolepis canadensis (Actinopterygii). In Schultze, H.-P. \& Cloutier, R. (eds). Devonian Fishes and Plants of Miguasha: 165-197, Verlag Dr. F. Pfeil, München.

Arratia, G., Scasso, R. \& Kiessling, W. 2004. Late Jurassic fishes from Longing Gap, Antarctic Peninsula. - Journal of Vertebrate Paleontology 24 (1): 41-55.

Bemis, W. E., Findeis, E. K. \& Grande, L. 1997. An overview of Acipenseriformes. - Environmental Biology of Fishes 48: $25-71$.

Bonaparte, J. 1997. El triásico de San Juan-La Rioja, Argentina, y sus dinosaurios. 190 pp., Museo Argentino de Ciencias Naturales "Bernardino Rivadavia", Buenos Aires.

Bossi, G. E. 1971. Análisis de la Cuenca Ischigualasto-Ischichuca. Primer Congreso Hispano-Luso-Americano de Geológica Económica, Madrid, v. 2, Sección I: 23-38.

Brough, J. 1939. The Triassic Fishes of Besano, Lombardy. 117 pp., British Museum, London.

Cabrera, A. 1944. Dos nuevos peces ganoideos del Triásico argentino. - Notas del Museo de La Plata, Paleontología 9 (81): 569-576.

Cloutier, R. \& Arratia, G. 2004. Early diversification of actinopterygians. In Arratia, G., Wilson, M. V. H. \& Cloutier, R. (eds). Recent Advances in the Origin and Early Radiation of Vertebrates: pp. 217-270, Verlag Dr. Friedrich Pfeil, München.

Contreras, V. H., Bracco, A. \& Sill, W. 1997. Primer registro de restos de tetrápodos en la Formación Los Rastros (Triásico Medio), Parque Provincial Ischigualasto, San Juan, Argentina. Ameghiniana 34 (4): 534 (abstract).

Cope, E. D. 1887. Zittel's manual of palaeontology. - American Naturalist 21: 1014-1019.

De la Mota, H. 1946. Estudios geológicos en el Cerro Bola al sur de Villa Unión, Departmento General Lavalle, Provincia de La Rioja. 145 pp., unpublished Ph.D. Thesis, Instituto del Museo de La Plata.

Egerton, M. G. 1864. On some ichthyolites from New South Wales. - Quarterly Journal of the Geological Society of London 20: 1-5.

Gallego, O. F. 1997. Hallazgos de insectos Triásicos en la Argentina. - Ameghiniana 34: 511-516.

Gardiner, B. G. 1969. New palaeoniscoid fish from the Witteberg series of South Africa. - Zoological Journal of the Linnean Society 48: 423-452.

Gardiner, B. G. \& Schaeffer, B. 1989. Interrelationships of lower actinopterygian fishes.- Zoological Journal of the Linnean Society 97: 135-187.

Grande, L. \& Bemis, W. E. 1996. Interrelationships of Acipenseriformes, with comments on "Chondrostei". In Stiassny, M. L. J., Parenti, L. R. \& Johnson, G. D. (eds). Interrelationships of Fishes: 85-115, Academic Press, San Diego.

Heyler, D. 1969. Vertébrés de l'Autunien de France. 255 pp., Centre National de la Recherche Scientifique, Paris.

Hilton, E. J. 2004. The caudal skeleton of Acipenseriformes (Actinopterygii: Chondrostei): recent advances and new observations. In Arratia, G., Wilson, M. V. H. \& Cloutier, R. (eds). Recent Advances in the Origin and Early Radiation of Vertebrates: pp. 599-617, Verlag Dr. Friedrich Pfeil, München. 
Huene, F. von 1931. Die fossilien Fährten im Rhät von Ischigualasto in Nordwest-Argentinien. - Palaeobiologica 4 (2): 99-112. Wien.

Hutchinson, P. 1973. A revision of the redfieldiiform and perleidiform fishes from the Triassic of Bekker's Kraal (South Africa) and Brookvale (New South Wales). - Bulletin of the British Museum (Natural History), Geology 22: $233-354$

Huxley, T. H. 1880. On the applications of the laws of evolution to the arrangement of the Vertebrata and more particularly of the Mammalia. - Proceedings of the Zoological Society of London 1880: 649-622.

Jollie, M. 1962. Chordate Morphology. XIV + 478 pp., Rheinhold Books, New York.

Jubb, R. A. 1965. A new palaeoniscid fish from the Witteberg Series (Lower Carboniferous) of South Africa. Annals of the South African Museum 48: 267-273.

Leidy, J. 1857. Notices of some remains of extinct fishes. Proceedings of the Academy of Natural Sciences of Philadelphia 9: 167-168.

López-Arbarello, A. 2004. The record of Mesozoic fishes from Gondwana (excluding India and Madagascar). In Arratia, G. \& Tintori, A. (eds). Mesozoic Fishes 3 - Systematics, Paleoenvironments and Biodiversity: 597-624, Verlag Dr. Friedrich Pfeil, München.

Long, J. 1988. New palaeoniscoid fishes from the Late Devonian and Early Carboniferous of Victoria. - Memoir of the Association of Australasian Palaeontologists 7: $1-64$.

- 1991. The long history of Australian fossil fishees. In Vickers-Rich, P., Monaghan, J. M., Baird, R. F. \& Rich, T. (eds). Vertebrate Palaeontology of Australasia: chapter 12: 337-428, Pioneer Design Studio, Melbourne.

Lund, R. 2000. The new Actinopterygian order Guildayichthyiformes from the Lower Carboniferous of Montana (USA). - Geodiversitas 22 (2): 171-206.

Lund, R., Poplin, C. \& McCarthy, K. 1995. Preliminary analysis of the interrelationships of some Paleozoic Actinopterygii. - Geobios M. S. 19: 215-220.

Mancuso, A. C. 2003. Continental fish taphonomy: a case study in the Triassic of Argentina. - Journal of South American Earth Science 16: 275-286.

Marsicano, C., Gallego, O. \& Arcucci, A. 2001. Faunas del Triásico: relaciones, patrones de distribución y sucesión temporal. In Artabe, A. E., Morel, E. M. \& Zamuner, A. B. (eds). El Sistema Triásico en la Argentina: 131-141, Fundación Museo de La Plata "Francisco Pascasio Moreno", La Plata.

Milana, J. P. \& Alcober, O. 1994. Modelo tectosedimentario de la cuenca Triásica de Ischigualasto (San Juan, Argentina). - Revista de la Asociación Geológica Argentina 49: 217-235.

Morel, E. M., Stipanicic, P. N. \& Zúñiga, A. 2002a. Cacheuta (Formación, Estratos de ...). In Stipanicic, P. N. \& Marsicano, C. A. (eds). Léxico Estratigráfico de la Argentina. Volumen VIII. Triásico: 50-52, Asociación Geológica Argentina, Buenos Aires, Serie "B" (Didáctica y Complementaria) 26, Buenos Aires.

- 2002b. Potrerillos (Formación, Estratos de ...). In Stipanicic, P. N. \& Marsicano, C. A. (eds). Léxico Estratigráfico de la Argentina. Volumen VIII. Triásico: 222-223, Asociación Geológica Argentina, Buenos Aires, Serie "B" (Didáctica y Complementaria) 26, Buenos Aires.

Mutter, R. J. 2002. Revision of the Triassic Family Colobodontidae sensu Andersson 1916 (emended) with a tentative assessment of perleidiform interrelationships (Actinopterygii: Perleidiformes). 337 pp., unpublished Ph.D. Thesis, Universität Zürich, Zürich.

- 2004. The "perleidiform" family Colobodontidae: A review. In Arratia, G. \& Tintori, A. (eds). Mesozoic Fishes 3 - Systematics, Paleoenvironments and Biodiversity: 197-208, Verlag Dr. Friedrich Pfeil, München.
Nielsen, E. 1942. Studies on Triassic Fishes 1: Glaucolepis and Boreosomus. - Meddelelser om Grønland 138: 1-394.

Patterson, C. 1982. Morphology and interrelationships of primitive actinopterygian fishes. - American Zoologist 22: 241-259.

Poplin, C. 1997. Le premier Haplolépiforme (Pisces, Actinopterygii) découvert en France (Carbonifère supérieur du bassin de Blanzy-Montceau, Massif central). - Comptes Rendus de l'Academie des Sciences, Paris 324 (IIa): 59-66.

- 2001. Le genre Bourbonnella (Actinopterygii, Aeduellidae): révision et description d'une nouvelle espèce du Stéphanien (Carbonifère supérieur) de Montceau-les Mines (Massif Central, France). - Annales de Paléontologie 87 (4): 231-248.

Ramos, V. A. \& Kay, S. M. 1991. Triassic rifting and associated basalts in the Cuyo basin, central Argentina. In Harmon, R. S. \& Rapela, C. W. (eds). Andean Magmatism and its Tectonic Setting: 79-91, Geological Society of America Special Paper 265.

Rogers, R. R., Arcucci, A. B., Abdala, F., Sereno, P. C., Forster, C. A. \& May, C. L. 2001. Paleoenvironment and taphonomy of the Chañares Formation tetrapod assemblage (Middle Triassic), Northwestern Argentina: spectacular preservation in volcanogenic concretions. - Palaios 16: $461-481$.

Rogers, R. R., Swisher, C. C. I., Sereno, P. C., Monetta, A. M., Forster, C. A. \& Martínez, R. N. 1993. The Ischigualasto tetrapod assemblage (Late Triassic, Argentina) and ${ }^{40} \mathrm{Ar} /{ }^{39} \mathrm{Ar}$ dating of dinosaur origins. - Science 260: 794-797.

Rusconi, C. 1946. Peces triásicos de Mendoza. - Sociedad Científica Argentina, Anales 141: 148-153.

- 1949a. Sobre un pez pérmico de Mendoza. - Revista del Museo de Historia Natural de Mendoza 3: 221-230.

- 1949b. Acerca del pez pérmico Neochallaia minor y otras especies. - Revista del Museo de Historia Natural de Mendoza 3: 231-236.

Schaeffer, B. 1984. On the relationships of the Triassic-Liassic redfieldiiform fishes. - American Museum Novitates 2795: $1-18$.

Schaeffer, B. \& Mac Donald, N. G. 1978. Redfieldiid fishes from the Triassic-Liassic Newark Supergroup of eastern North America. - Bulletin of the American Museum of Natural History 159: 129-173.

Schultze, H. P. 1993. Patterns of diversity in the skulls of jawed fishes. In Hanken, J. \& Hall, B. K. (eds). The Skull. Volume 2. Patterns of Structural and Systematic Diversity: 189-254, The University of Chicago Press, Chicago and London.

Schultze, H.-P. \& Arsenault, M. 1985. The panderichthyid fish Elpistostege: A close relative to tetrapods? Palaeontology 28: 293-309.

Stipanicic, P. N. 1983. The Triassic of Argentina and Chile. In Moullade, M. \& Nairn, A. E. M. (eds). The Phanerozoic Geology of the World. The Mesozoic, B: 181-199, Elsevier Press, Amsterdam.

- 2002. Introducción. El Triásico en la Argentina. In Stipanicic, P. N. \& Marsicano, C. A. (eds.). Léxico Estratigráfico de la Argentina. Volumen VIII. Triásico: 1-24, Asociación Geológica Argentina, Serie "B" (Didáctica y Complementaria) 26, Buenos Aires.

Stipanicic, P. N. \& Bonaparte, J. F. 1979. Cuenca Triásica de Ischigualasto-Villa Unión (Provincia de La Rioja y San Juan). - II Symposio de Géología Regional Argentina 1: $523-575$.

Stipanicic, P. N. \& Bossi, G. 2002. Los Rastros (Formación ...). In Stipanicic, P.N. \& Marsicano, C.A. (eds). Léxico Estratigráfico de la Argentina. Volumen VIII. Triásico: 184-185, Asociación Geológica Argentina, Serie "B" (Didáctica y Complementaria) 26, Buenos Aires. 
Tintori, A. \& Sassi, D. 1992. Thoracopterus Bronn (Osteichthyes: Actinopterygii): a gliding fish from the Upper Triassic of Europe. - Journal of Vertebrate Paleontology 12 (3): 265-283.

Traquair, R. H. 1893. On a new palaeoniscid fish, Myriolepis hibernicus, sp. nov. from the Coal-measures, Co. Kilkenny, Ireland. - Gelogical Magazine, Decade 3, 10 (344): 54-56.

Uliana, M. A. \& Biddle, K. Y. 1988. Mesozoic-Cenozoic paleogeographic and geodynamic evolution of southern South America. - Revista Brasilera de Geosciencias 18: 172-190.

Wade, R. T. 1935. The Triassic fishes of Brookvale, New South Wales. 110 pp., British Museum (Natural History), London.

Wenz, S. 1959. Étude de Ptycholepis bollensis, Poisson du Lias supérieur de l'Yonne et du Würtemberg. - Bulletin de la Société géologique de France, sér. 7, 1: 916-928.
Westoll, T. S. 1944. The Haplolepidae, a new family of Late Carboniferous bony fishes. A study in taxonomy and evolution. - Bulletin of the American Museum of Natural History 83: 1-122.

White, E. I. 1933. New Triassic Palaeoniscid from Madagascar. - Annual Magazine of Natural History, ser. 10, 11: 118-128.

Woodward, A. S. 1890. The fossil fishes of the Hawkesbury series at Gosford. - Memoirs of the Geological Survey of New South Wales, Palaeontology 4: 1-55.

- 1908. The fossil fishes of the Hawkesbury Series at St. Peter's. Memoirs of the Geological Survey of New South Wales, Palaeontology 10 (8125): $5+31$ pp., 4 pl.

Zavattieri, A. M. \& Batten, D. J. 1996. Miospores from Argentinian Triassic deposits and their potential for intercontinental correlation. In Jansonius, J. \& Mc Gregor, D. C. (eds). Palynology: Principles and applications: 767778, American Association of Stratigraphic Palynologists Foundation. 